\title{
Az európai növekedési modell kifulladása
}

\author{
„A gyors gazdasági növekedés révén \\ megvalósuló felzárkózás jelentőségét \\ tekintve az atomenergia megszelídítésével \\ mérhetö össze." (Fei-Ranis [1997] ${ }^{*}$
}

Az európai integráció a preferenciális liberalizációtól a mélyebb integráció lépcsőfokáig terjedően egyaránt lényeges hatást gyakorol a gazdasági növekedés folyamataira. Meghatározó jelentőségü, hogy feltárjuk a tényezőpiaci integráció termelékenységi hatásainak mechanizmusát. Mindezek alapján azonosíthatók az elmúlt több mint fél évszázadnyi időszakban müködő európai növekedési modell fő sajátosságai. A rejtett erózió után a legutóbbi pénzügyi és gazdasági válság világossá tette e modell kifulladását. Ám mindez egyúttal új lehetőséget (s egyben kényszert) jelent a cselekvésre, a fordulatra. Az európai modell újrafogalmazása s az európai növekedési képesség megújítása megkerülhetetlen tényezői az európai integráció megújításának is. Az Európai Unióban koordinált strukturális reformokra épülő növekedési program szükséges. Csak a gazdasági racionalitás, a nemzetközi versenyképesség és a tudásgazdaság előtérbe helyezésén nyugvó megoldások lehetnek hosszú távon eredményesek. Mindezeknek az erőfeszítéseknek általános célja, hogy helyreálljon Európa „gazdasági prosperitásának háromszöge”: a gazdasági növekedés, a stabilitás és a méltányosság a nyitott és demokratikus társadalmakban. ${ }^{* *}$ Journal of Economic Literature (JEL) kódok: F15, F16, F43, F45, O43, O47.

A gazdasági integráció eredményességének kézenfekvő mércéje a gazdasági növekedésre, a növekedési potenciálra gyakorolt hatása. A növekedési ütem akár csekély eltérése is idővel jelentős különbségeket idézhet elő az egyes országok, országcsoportok fejlettségében, jövedelmi szintjében.

* Idézi: Snowdon-Vane [2006] 615. o.

** A cikk a 2017. március 22-én megtartott akadémiai székfoglaló előadás szövege. A tanulmány a KÖFOP 2.1.2-VEKOP-15-2016-00001 azonosítószámú, A jó kormányzást megalapozó közszolgálatfejlesztés elnevezésü kiemelt projekt és a Magyary Chair program keretében készült.

Halmai Péter az MTA levelezö tagja, egyetemi tanár, Nemzeti Közszolgálati Egyetem (e-mail: halmai. peter@uni-nke.hu).

A kézirat első változata 2017. november 16-án érkezett szerkesztőségünkbe.

DOI: http://dx.doi.org/10.18414/KSZ.2018.2.122 
A gazdasági növekedés nemcsak a közgazdászok számára lényeges dimenzió. Benjamin M. Friedman a következőképpen ír: az emberek nemcsak másokkal hasonlítják össze magukat a jelenben, hanem az elmúlt időszak embereivel, közöttük korábbi önmagukkal. „A gazdasági növekedés pozitív hatása az emberek mentalitására, majd a politikai folyamatokon keresztül a társadalomra abban a kölcsönösségben rejlik, ahogyan ez a két viszonyítási pont az emberek felfogását befolyásolja. ... az nagyon is lehetséges, hogy a legtöbb ember jobban éljen, mint korábban élt, és a gazdasági növekedés pontosan ezt jelenti." (Friedman [2010] 102. o.) A gazdasági növekedés a békét és a toleranciát segíti elő. A lassuló gazdasági növekedés - eltérő, néha hosszú - időbeli késésekkel intoleranciához, agresszív nacionalizmushoz és háborúhoz vezet.

A gazdasági növekedés tekintetében közepes és hosszú távon kínálati oldali tényezők a meghatározók: a munka, a tőke és a teljes tényezőtermelékenység (total factor productivity, TFP). A növekedési tényezők mennyiségén túl különös jelentőségű a legutóbbi. A neoklasszikus növekedési modellben - a Nobel-díjas Robert Solow nyomán - Solow-maradéknak nevezik a gazdasági növekedésnek a növekedési tényezők mennyiségi változásán túlmenő elemeit. E „maradék” heterogén tartalmú: a műszaki haladáson túl a széles értelemben vett innováció, az intézményrendszer, a makrogazdasági politikák, a bizalom, a társadalmi értékrend és a kultúra hatásai egyaránt beletartoznak. (A gazdasági növekedés elemzési rendszerét az 1. ábra foglalja össze.)

A növekedési folyamatokban meghatározó jelentőségü a fizikai, az emberi - benne a tudás- - tőke endogén, a gazdasági rendszer sajátosságait tükröző akkumulációja.

Meg kell különböztetni az aktuális és a potenciális kibocsátás, illetve növekedés kategóriáit. A gazdaság közvetlenül mérhető teljesítménye az aktuális kibocsátás. A potenciális kibocsátás a gazdaság ciklikus tényezőktől megtisztított kibocsátási kapacitása, a tartósan fenntartható egyensúlyi (steady state) kibocsátás szintje. A potenciális növekedés a potenciális kibocsátás dinamikája, a tartósan fenntartható növekedés pályája. Ha az aktuális kibocsátás meghaladja a potenciális kibocsátás szintjét, pozitív előjelü kibocsátási rés (output gap) alakul ki. Ez a gazdaság túlfütöttségét jelzi. A negatív előjelü kibocsátási rés pedig az egyensúly sérelme nélkül is mozgósítható kapacitástartalékra utal.

Az integráció és a növekedés a makroökonómiai és a nemzetközi gazdaságtani elmélet alapvetö fontosságú témakörei. Ez utóbbi vizsgálata során lényeges az empirikus módszerek, a kiterjedt mennyiségi elemzések alkalmazása. Közülük kiemelést érdemel a termelésifüggvény-alapú megközelítésen nyugvó növekedési számvitel (growth accounting). A kvantitatív elemzések lehetőségei a legutóbbi évtizedekben rendkívüli mértékben kibővültek. Lehetségessé vált igen nagy adatbázisok kezelése, hatalmas adatmennyiségek feldolgozása, paneladatok széles körü felhasználása, a kiterjedtebb elemzésekre módot nyújtó programcsomagok, ökonometriai módszerek, modellek alkalmazása.

A tárgyalt témakör mélyebb feltárásához a komparatív, intézményi és történeti megközelítés egyidejủ érvényesítése is szükséges. A különféle módszerek összekapcsolása alapvetö követelmény a gazdaságtörténeti és a közgazdaságtani elemzésben: 
1. ábra

A gazdasági növekedés elemzési rendszere
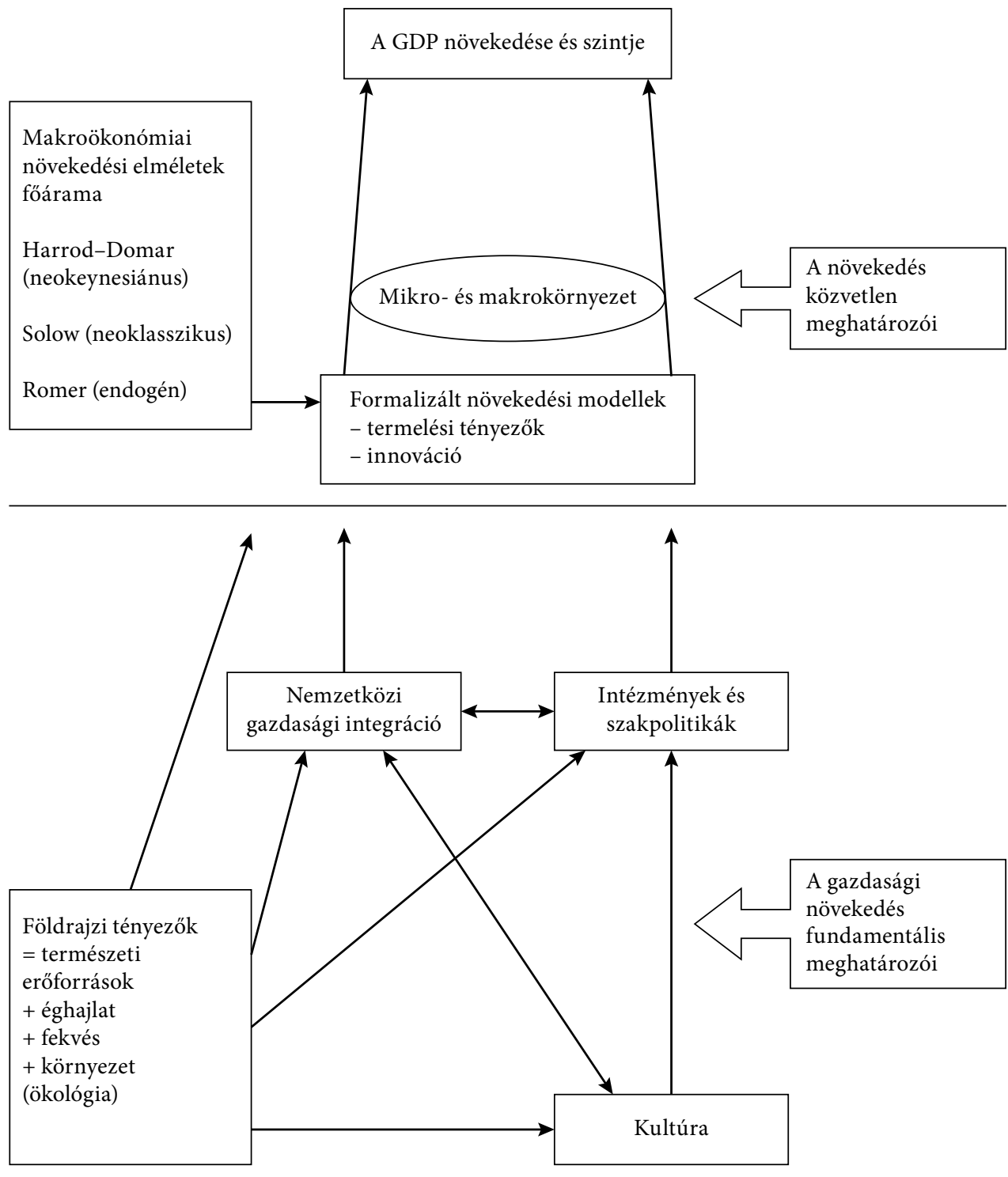

gondoljunk például az ún. kliometriai forradalomra, azaz a széles körủ mennyiségi elemzések alkalmazására a gazdasági evolúció leírásában (egyebek mellett Maddison [1987], [1996] vagy Crafts [2012], illetve Crafts-Toniolo [2008] e témakörben is releváns müveiben).

A történeti megközelítés fontosságát kiemelve C. Goldin a következőképpen fogalmaz: „A múlt maradványai, amelyek a lehetséges ma birodalmát formálják, állandóan velünk vannak, normák, struktúrák, intézmények, sőt emberek." (Goldin [1995] 191-192. o.) A Nobel-díjas D. North az útfüggőség, a történelmi örökség szerepét hangsúlyozza: 
„A történelem számít... a mai és a holnapi választásokat a múlt alakítja, és a múltat csak az intézményi evolúció történeteként lehet megérteni." (North [1990] 59. o.)

Az európai integráció - hosszabb időszakok előzetes víziói után - immáron közel hét évtizede egyre mélyülő realitás. Az elmúlt évtizedekben az európai integráció folyamatában sajátos európai növekedési modell alakult ki. A növekedési potenciál feltárásával szembesíthetjük az európai és tagállami valóságot a vágyakkal. Az európai növekedési modell a sikeres évtizedek után egyre növekvő kihívásokkal került szembe. A 2008 őszén kezdődött „nagy recesszió” után csak lassú és országonként eltérö ütemü a kilábalás.

Fontos évforduló elött állunk. 1957. március 25-e emblematikus jelentőségü, az Európai Gazdasági Közösséget megalapító egykori római szerződés aláírásának időpontja. A szimbólumok nagy jelentőségűek az európai integrációban. Rómában a capitoliumi palota Horatiusok és Curiatiusok terme volt a közösség alapításának csodálatos helyszíne. A kor legnagyobb európai államférfiúi, európai vízióval rendelkező gondolkodói alkották meg az európai integráció szerződéses alapjait. A víziók valósággá váltak, s újabb víziókra volt és van szükség. A hatvanadik évforduló leltár és számvetés készítésére is alkalmat ad.

Az ünneplés nem lehet felhőtlen. A brit miniszterelnök asszony levele sem születésnapi jókívánságokat tartalmaz, hanem a brit kilépés, a brexit folyamatának hivatalos kezdeményezését.

Az előadás három fö kérdést tárgyal. Az európai növekedési folyamatok alakulását, az európai növekedési modell sajátosságait vizsgálja az integráció kezdetétől; majd e modell eróziójának, illetve válságának fö jellemzőit taglalja; végül a növekedési fordulat lehetőségeit tekinti át.

\section{Az európai növekedési modell}

\section{Európai növekedési folyamatok}

Az 1950 és 1973 közötti időszak az európai növekedés „aranykora” volt (Eichengreen [2007]). E növekedési aranykor az európai integráció mindeddig talán legintenzívebb időszaka volt. Mindez elgondolkodtató az integráció és a gazdasági növekedés összefüggésének tekintetében is.

1950 és 1973 között a GDP növekedési üteme - a korábbi időszakhoz képest - több mint háromszorosára, az egy főre jutó GDP bővülésének üteme pedig csaknem négyszeresére növekedett. E dinamika esetén az egy före jutó jövedelmek 18,6 év alatt kétszereződnek meg. Ilyen ütem esetén - átlagos élettartamot feltételezve - az életszínvonal megnégyszereződhetne egy-egy uniós polgár számára. Az egy órára jutó hozzáadott érték pedig csaknem ötszörösére bővült.

Az aranykor a felzárkózási növekedés időszaka volt. A vezető szerep az Egyesült Államoknak jutott, de az 1950-es évektől egészen a kilencvenes évtized közepéig az európai országok csökkentették jövedelmi és termelékenységi elmaradásukat. Az 1 . táblázat szerint az 1950 és 1973 közötti időszakban a későbbi EU15 országokban a 
GDP, az egy före jutó GDP, az egy dolgozóra és az egy ledolgozott munkaórára jutó hozzáadott érték is jóval gyorsabban nőtt, mint az Egyesült Âllamokban. A 2. táblá$z a t$ szerint pedig ebben az időszakban jelentős konvergencia valósult meg az egy före jutó GDP, illetve az egy ledolgozott munkaórára jutó hozzáadott érték tekintetében.

\section{1. táblázat}

A kibocsátás és a termelékenység éves növekedési ütemei az EU15-ben és az Egyesült Államokban, 1950-2007 (százalék)

\begin{tabular}{lcccc}
\hline & GDP & GDP/fó & GDP/dolgozó & GDP/ledolgozott munkaóra \\
\hline 1950-1973 & & & & \\
EU15 & 5,97 & 4,05 & 4,15 & 4,80 \\
Egyesült Államok & 3,92 & 2,45 & 2,30 & 2,56 \\
\hline $1973-1995$ & & & & 2,69 \\
EU15 & 2,25 & 1,89 & 2,00 & 1,28 \\
Egyesült Államok & 2,86 & 1,80 & 1,12 & 1,17 \\
1995-2007 & & & & 2,05 \\
EU15 & 2,58 & 1,80 & 0,92 & \\
Egyesült Államok & 3,17 & 2,11 & 1,92 & \\
\hline
\end{tabular}

Megjegyzés: reálértékben számított GDP.

Forrás: Crafts [2012].

\section{2. táblázat}

Az EU15 termelékenységének egyes tényezői az Egyesült Államok megfelelő mutatóinak arányában

\begin{tabular}{lcccc}
\hline & $Y / P$ & $Y / H W$ & $H W / E$ & $E / P$ \\
\hline 1950 & 0,482 & 0,381 & 1,190 & 1,063 \\
1973 & 0,680 & 0,629 & 1,092 & 1,000 \\
1995 & 0,700 & 0,853 & 0,974 & 0,843 \\
2007 & 0,675 & 0,769 & 0,947 & 0,928 \\
\hline
\end{tabular}

Megjegyzés: a táblázat a következő azonosságot mutatja: $Y / P=Y / H W \times H W / E \times E / P$ az EU15/Egyesült Államok arányában, ahol Y: a GDP reálértékben, $P$ : a népesség száma, $H W:$ a ledolgozott munkaórák száma, $E$ : a dolgozók száma.

Forrás: Crafts [2012] 30. o. 5. táblázat.

Az 1950 és 1973 közötti időszakban az Európai Gazdasági Közösség tagállamaiban a bruttó megtakarítások GDP-hez viszonyított aránya - ahogyan Berend [2016] kimutatta - a megelőző korszakhoz képest átlagosan a kétszeresére nőtt (a bruttó hazai termék 12-14 százalékáról mintegy 25 százalékára). Ennek bázisán „az európai tőkeképződés és beruházás a 20 . század második felében minden addiginál sokszorosan magasabb szintet ért el" (Berend [2008] 230. o.). 
Ugyanakkor indokolt az élvonaltól távoli, illetve az élvonalhoz közeli gazdaságok felzárkózási növekedésének a megkülönböztetése. Az elsőként említett esetben a teljes tényezőtermelékenység gyors növekedése érhető el a produktív és az allokációs hatékonyság növelése, továbbá a technológia importja révén. Ez átmeneti szakasz, amelyben a növekedés gyors lehet. Lényegében ez volt az európai növekedés aranykorának tartalma. Ebben az időszakban alapvető strukturális változás ment végbe: a mezőgazdaság részesedése gyorsan csökkent a foglalkoztatásban (Crafts-Toniolo [2008]). A felzárkózás előrehaladásával a technológiai fejlődés hajtóereje megváltozik: az utánzásról az innovációra kerül a hangsúly. A fejlődés e következő szakaszának megvalósításához reformokra volt szükség. Ám e változások Európában lassúnak bizonyultak (Eichengreen [2007]). ${ }^{1}$

Azok az intézmények és politikai választások, amelyek az élvonaltól távolabb elhelyezkedő gazdaságot élénkítik, sok tekintetben különböznek az élvonalhoz közeli gazdaság számára megfelelőktől (Aghion-Howitt [2006]). Az utóbbi esetében különösen fontossá válik a termékpiacon folytatott verseny erősítése, a minőségi oktatás kiépítése, továbbá az intézmények és politikák reformja. Ám a szükséges alkalmazkodás sok nehézséggel jár. Nagy figyelmet igényel az útfüggőség, a történelmi örökség. A szükséges változások gyakran csak lassan és tökéletlenül érhetők el. Ezért a felzárkózási növekedés e körülmények között akadozhat. (Az egy före jutó GDP mind NyugatEurópában - lásd a 2. táblázatot -, mind Japánban 2007-ben hasonló arányt képviselt az Egyesült Államok szintjéhez képest, mint 1973-ban.)

A gyors európai növekedés az 1950-es és 1960-as években a magas beruházási rátán, illetve az amerikai ipari technológia diffúzióját előmozdító politikán és intézményeken alapult. E korszakban a „koordinált piacgazdaságok” (Hall-Soskice [2001]) müködése dominált. Jellemző volt a szélesebb körü állami intervenció a szabályozás, az állami tulajdon és az iparpolitika területén.

Néhány országban, különösen Észak-Európában a felzárkózást korporatív „társadalmi szerződések” segítették, amelyek a tőke és a munka közötti alkuegyensúlyon alapultak, ${ }^{2} \mathrm{~s}$ valamiféle módon a beruházásokat kívánták előmozdítani a bérek viszonylagos visszatartása révén (Eichengreen [2007], Berend [2008] 186-189. és 205-208. o.). A növekvő beruházások előmozdították a tőkeintenzitás növekedését, illetve új technológiák elterjedését, ezek révén pedig a gazdasági növekedést. Másutt (például Olaszországban) a növekedést a munka rugalmas kínálatán, illetve az alulértékelt valután alapuló iparosítás segítette elő. Ez utóbbi előmozdította a beruházást, s lehetővé tette a belső méretgazdaságosság megvalósítását az ipari ágazatokban (Crafts [2012]). Az európai gazdasági növekedés gyorsulásában kiemelkedő szerepet játszott a kereskedelmi liberalizáció is.

Ám az aranykor mintegy negyedszázad után véget ért. Az azt követő két évtizedben (1973 és 1992 között) az egy före jutó GDP már csak 1,7 százalékkal nőtt évente. A munkaidő azonban tovább rövidült, s az egy órára jutó GDP 2,7 százalékkal

${ }^{1}$ Jánossy [1966] németül Das Ende der Wirtschaftswunder címmel megjelent, nagy vitát kiváltó művében már az „aranykor” időszakában a tudástőke központi szerepét s az annak intézményi korlátaiból adódó növekedéslassulás szükségszerüségét hangsúlyozta.

${ }^{2}$ A tőke és a munka közötti alkuegyensúlyt Eichengreen-egyensúlynak is nevezik. 
emelkedett (lásd a 2. táblázatot). Az aranykor végének számos elkerülhetetlen vonatkozása volt. A gyors növekedés átmeneti forrásai (a háború utáni helyreállítás, a mezőgazdaságból történő tömeges munkaerő-kiáramlás) kimerültek. Ugyanakkor szükült a technológiai rés, csökkent a beruházások megtérülése. A termelékenység növekedése az Egyesült Államokban is mérséklődött. A felzárkózási növekedés is jelentős mértékben lassult, ám nem szűnt meg. Az aranykort követő két évtizedben a munkatermelékenység továbbra is gyorsabban nőtt az EU15 tagállamaiban, mint az Egyesült Államokban.

Ám az egy före jutó GDP-ben mért felzárkózás csaknem teljesen eltünt. Erre a munkaerőpiaci fejlemények adtak magyarázatot: az európai országokban megnőtt a munkanélküliség, míg a munkában töltött évek száma, illetve az átlagos munkaidő csökkent. (A korai nyugdíjazás elterjedése, a szabadság időtartamának növekedése, a heti munkaidő rövidítése egyaránt ebben az irányban hatottak.) Mindezek mögött a piaci torzulások kombinációja és a preferenciák különbségei egyaránt megtalálhatók. Egyrészt a strukturális munkanélküliség hosszú távú alakulása érdemel figyelmet. Az 1960-as évek vége és az 1990-es évek eleje között - alapvetően a makrogazdasági problémákra hivatkozva - alkalmazott szakpolitikai lépések (munkaidő-szabályozás, foglalkoztatásvédelem, implicit adók, várt helyettesítési ráták stb.), illetve a kollektív alkumechanizmusok egyaránt a munkakínálat csökkenésének irányában hatottak. Az európai integráció elörehaladásával párhuzamosan egészen 1995-ig mérsékelt jövedelmi konvergenciát lehetett kimutatni Európa és az Egyesült Államok között. ${ }^{3}$

Az egy munkaórára jutó reál-GDP a nyugat-európai országokban az 1973. évi 62,9 százalékról 1995-re 85,3 százalékra emelkedett az Egyesült Államok szintjéhez képest, vagyis a termelékenységi rés ebben az időszakban tovább szükült (lásd a 2. táblázatot).

A termelékenység növekedése azonban lelassult. Az 1970-es évek turbulenciáit nem élte túl az Eichengreen által jelzett bér-beruházás-alkumechanizmus. A szakszervezetek alkuereje megnőtt. Egyidejűleg erősödött a foglalkoztatottak védelme, valamint növekedett a munka részesedése a hozzáadott értékből. Egyidejűleg megszűnt a rögzített árfolyamok rendszere, általánossá vált a valuták lebegése, s megnőtt a tőke mobilitása. A gazdasági növekedés korporativista modellje kevésbé felelt meg az innovációt igénylő gazdaságokban, amelyekben az utánzás alapján már csak csekély lehetőség nyílott a termelékenység további javítására (Eichengreen [2007]). Az európai gazdaságok strukturális merevségei azonban lelassították az innovatív technológiák alkalmazását.

Ugyanakkor a felzárkózási növekedés, majd az 1970-es évektől kezdődő makrogazdasági zavarok nagymértékben fokozták a szociális védelem, a transzferek iránti igényt. Ennek meghatározó tényezői valószínűleg a munkakínálatot csökkentő szakpolitika, a korábbi korporativista társadalmi szerződések utóhatásai, illetve az 1970-es évek turbulens makrogazdasági feltételei voltak. A nyugat-európai gazdaságok átlagában 1960ban a GDP 10,5, 1980-ban pedig már 21,1 százalékát fordították szociális transzferekre, míg 1930-ban csak 1,2 százalék volt ezek részesedése (Crafts [2012]).

\footnotetext{
${ }^{3}$ A vásárlóerő-standardban kifejezett egy före jutó GDP a nyugat-európai országokban az Egyesült Államok hasonló mutatójához képest az 1973. évi 68 százalékról 1995-re 70 százalékra emelkedett (2. táblázat).
} 
A többletkiadásokat jelentős részben torzító hatású adókból fedezték. A közvetlen adóknak a GDP-hez képest mintegy 10 százalékpontos 1965 és 1995 közötti emelkedése az évi növekedési ütem mintegy 1 százalékpontos mérséklődésével járt (Kneller és szerzőtársai [1999]). Ugyanakkor a foglalkoztatásvédelem magas szintje lassította a munkaerő alkalmazkodásának folyamatait. A foglalkoztatásvédelem különbsége Franciaország és az Egyesült Államok között az 1980-as és 1990-es években évi 0,5 százalékos különbséget okozhatott a munkatermelékenység növekedési ütemében (Caballero és szerzőtársai [2004]).

\section{Növekedés és európai integráció}

Az integráció érdemi hatást gyakorol a gazdasági növekedésre: a gyors és átfogó kereskedelmi liberalizáció - különösen az 1960-as években - igen jelentős növekedést eredményezett. (Az EU15 átlagos vámszintje eröteljesen mérséklődött az 1950-2000-es időszakban.) Rendkívül lényeges mértékben csökkentek a kereskedelmi költségek (3. táblázat). Az EGK-tagság a kereskedelmi költségek csökkentése révén az alapító Hatok jövedelmi szintjét 1970-re mintegy 8 százalékkal emelte (Boltho-Eichengreen [2008]).

\section{3. táblázat}

A kereskedelmi költségek alakulása (Egyesült Királyság-Franciaország, 1929=1,00)

\begin{tabular}{ccccccc}
\hline & $\begin{array}{c}\text { Németország- } \\
\text { Franciaország }\end{array}$ & $\begin{array}{c}\text { Német- } \\
\text { ország- } \\
\text { Olaszország }\end{array}$ & $\begin{array}{c}\text { Spanyol } \\
\text { ország- } \\
\text { Franciaország }\end{array}$ & $\begin{array}{c}\text { Spanyol- } \\
\text { ország- } \\
\text { Olaszország }\end{array}$ & $\begin{array}{c}\text { Egyesült } \\
\text { Királyság- } \\
\text { Franciaország }\end{array}$ & $\begin{array}{c}\text { Egyesült } \\
\text { Királyság- } \\
\text { Olaszország }\end{array}$ \\
\hline 1929 & 0,99 & 1,10 & 1,18 & 1,63 & 1,00 & 1,22 \\
1938 & 1,33 & 1,12 & 2,26 & 1,74 & 1,21 & 1,54 \\
1950 & 1,12 & 1,27 & 1,55 & 2,40 & 1,22 & 1,36 \\
1960 & 0,91 & 1,01 & 1,52 & 1,54 & 1,22 & 1,25 \\
1970 & 0,73 & 0,79 & 1,24 & 1,42 & 1,10 & 1,21 \\
1980 & 0,55 & 0,61 & 0,89 & 1,08 & 0,74 & 0,86 \\
1990 & 0,53 & 0,56 & 0,74 & 0,87 & 0,70 & 0,84 \\
2000 & 0,61 & 0,66 & 0,70 & 0,87 & 0,75 & 0,90 \\
\hline
\end{tabular}

Megjegyzés: a kereskedelmi költségeket a gravitációs modell felhasználásával határozták meg; a kereskedelem politikai és nem politikai akadályait egyaránt tartalmazzák.

Forrás: Crafts [2012] 33. o. 7. táblázat.

Az európai integrációs folyamat nem állt meg és nem fordult vissza az 1950-es évek óta: azóta is a mélyülés, illetve a horizontális bővülés szakaszai követték egymást, illetve időben gyakran egybe is estek. E fejlődés lényeges növekedési és termelékenységi többletet eredményezett. Az európai integráció egyedülállóan sikeres: Európa az egyetlen régió a világon, ahol a feltétel nélküli (abszolút) 
$\beta$-konvergencia ${ }^{4}$ tartós érvényesülése empirikusan bizonyítható (Campos és szerzötársai [2014]). Az aranykort követő két évtizedben a munkatermelékenység továbbra is gyorsabban nőtt, mint az Egyesült Államokban. Ám a felzárkózás az egy före jutó GDP-ben, mint már láthattuk, csaknem megszünt.

Az EGK-tagállamok növekedési teljesítménye a tárgyalt évtizedekben csaknem 50 százalékkal volt jobb, mint az EFTA-tagországoké. E különbség jelentős része a felzárkózással magyarázható. Az EGK-tagállamokban az egy före jutó GDP 1950ben alacsonyabb volt, mint a későbbi EFTA-tagországokban. Az alacsonyabb jövedelmi szinttel jellemezhető európai országok pedig gyorsabban növekedtek, mint a náluk gazdagabbak.

Három - európai viszonylatban nagy - ország (Németország, Franciaország, Olaszország, az EGK alapítói) évi növekedési üteme 1950-1973 között 1,7-2,1-szerese volt az Egyesült Királyság dinamikájának. Ez utóbbi ország elmaradó növekedési teljesítménye - szemben a kontinentális növekedési boommal - lényeges szerepet játszott az EGK-tagsággal szemben tanúsított brit magatartás változásában.

Az 1970-es és 1980-as években az európai integráció kereskedelmi hatásaiból származó növekedési impulzusok csökkentek, de továbbra is hatottak. A világgazdasági válság körülményei között az 1973 utáni években a tagállamok egymás közötti kereskedelme is megtorpant. Az 1980-as évek elejétől azonban ismét nőtt az egymás közötti kereskedelem. Az 1973 és 1986 közötti időszakban a Hatok Tizenkettekké bővültek, ami ugyancsak jelentős kereskedelmi hatásokat eredményezett. Az Európai Közösségek kibővülése a kereskedelmi költségek lényeges csökkenésével járt (lásd a 3. táblázatot). Mindezek ellenére az EU egészét tekintve a jelzett időszakban a kereskedelemből eredő növekedés már csak csekély mértékü volt (Bayoumi-Eichengreen [1995]).

Az integráció mélyítésének jelentős lépése volt az egységes piac megteremtése az 1990-es évek elején. Ez egyértelmüen a versenyt támogató sokkhatást váltott ki az érzékeny ágazatokban, ami a teljes tényezőtermelékenység mintegy 2 százalékos növekedését eredményezte. Az egységes piac megteremtésének hatására tíz év alatt az Európai Unióban körülbelül 2 százalékkal nőtt a GDP, ami nem elhanyagolható eredmény, noha jóval csekélyebb, mint amit a Cecchini-jelentés 1988-ban a koncepció

\footnotetext{
${ }^{4}$ A Solow-modell szerint a szegényebb országok egy före jutó jövedelme gyorsabb ütemben növekszik, mint a gazdagabb országoké. A szegényebb országok felzárkóznak a gazdagabb országokhoz. Ez az úgynevezett abszolútkonvergencia-hipotézis. Ennek empirikus tesztelésére a növekedéselméleti irodalomban keresztmetszeti adatokon végzett lineáris regressziós becslést alkalmaznak. A magyarázó változók a vizsgálati időszak kezdetén megfigyelt jövedelmi adatok $\left(\ln y_{i 0}\right)$, ahol $i$ az ország indexe, a 0 jelöli a kiinduló időpontot. Magyarázott változó pedig a vizsgálati periódusban megfigyelt átlagos növekedési ütem, amelyet a jövedelmek logaritmusának egész periódus alatti változása mutat. A becsült regressziós egyenlet tehát:
}

$\Delta \ln y_{i}=\alpha+\beta \ln y_{i 0}+\varepsilon_{t}$.

$\mathrm{Az}$ egyenletben $\alpha, \beta$ az ismeretlen paraméterek, $\varepsilon_{t}$ képviseli a véletlen tényező hatását. A konvergenciahipotézis érvényességéhez a becsült $\beta$ paraméternek negatívnak kell lennie. Ebben az esetben a gazdagabb országok növekedési üteme alacsonyabb, következésképpen felzárkózás várható. Annak gyorsaságára szintén a $\beta$ paraméter adhat becslést. A $\beta$-konvergencia elnevezés is innen származik: a kérdéses jelenség, azaz a konvergencia szempontjából a regressziós egyenlet $\beta$ paramétere a meghatározó (Barro-Sala-i-Martin [2003]). 
teljes megvalósítása esetére lehetőségként elöre jelzett (Cecchini és szerzőtársai [1988], Boltho-Eichengreen [2008]).

Az integráció és a növekedés közötti kapcsolatok matematikai statisztikai módszerekkel is vizsgálhatók. Lényegében elméleti konszenzus áll fenn a gazdasági integráció és a kibocsátás növekedésének összefüggését illetően. Az európai integráció esetében az eddigi empirikus eredmények viszonylag korlátozottak. $\mathrm{H}$. Badinger kutatásai szerint a szorosabb európai integráció kimutatható középtávú növekedési hatást eredményez (Badinger [2005], [2008]). A hatásvizsgálat központi eleme e kutatások keretében a következő: a nemzetgazdasági teljesítmény integráció által indukált többletének feltárásához az integráció nélkül elérhető jövedelem nagyságának meghatározása szükséges.

A közelmúltban kifejlesztett módszer, a szintetikus kontrafaktuális (tényellentétes) elemzés új lehetőségeket nyújt az elemzésre (Imbens-Wooldridge [2009], Abadie és szerzőtársai [2010], [2012]). Az eljárás a valóság ellentétének becslésére alkalmazható. Segítségével lehetőség nyílik a tényleges és az attól eltérő, alternatív út kimenete közötti összehasonlításra, továbbá arra, hogy „újraírjuk a múltat”: megnézzük, mi történt volna, ha az eredetitől eltérö lehetőséget választottunk volna. A módszer felhasználásával feltételezett forgatókönyvek generálhatók. Mindezek révén becsülhetö, hogy mekkora lenne az egy főre jutó GDP és a munkatermelékenység szintje, ha az adott ország nem vált volna az EU tagjává. A szintetikus ellenőrző módszer valamely intervenció (például az EU-tagság) hatását becsüli, összehasonlítva valamely aggregált eredményváltozó (az egy före jutó GDP vagy a munkatermelékenység) változásával.

A szintetikus tényellentétes elemzés módszertana - az elvégzett kutatások szerint alkalmas lehet az EU-tagságból származó szignifikáns és lényeges növekedési többlet azonosítására. E növekedési és termelékenységi többletek pozitívak, jellemzően jelentősek és tartósak. Campos és szerzőtársai [2014] becslései szerint a vizsgált országok átlagában európai integráció nélkül az egy före jutó GDP 11-12 százalékkal lenne alacsonyabb a ténylegesen elért jövedelmi szintnél.

Az egyes országok helyzetében azonban lényeges eltérések lehetségesek. Írország esetében az 1980-as évek közepén kötött új „társadalmi szerződés”, az annak révén elért „Eichengreen-egyensúly” nyújthatott alapot a növekedési fordulatot s rendkívül gyors felzárkózást eredményező modernizációhoz. Görögországban pedig csak a populista tévelygés több mint évtizednyi időszaka után kezdődött viszonylagosan pragmatikus - ám továbbra sem ellentmondások nélküli - gazdaságpolitika.

A legnagyobb hatás Îrország esetében mutatható ki. Írország EU-tagként befutott növekedési pályája gazdaságtörténeti dimenzióban is „növekedési csodának” minősíthető. Ugyanez nem volna elmondható Írország alternatív, „szintetikus” pályájáról (2. ábra).

A nyitottság főleg két csatorna: a kereskedelem és a beruházás révén gyakorol hatást a termelékenységre. A növekvő kereskedelem elösegíti a verseny erősödését, amelynek révén az erőforrások a gazdaság termelékenyebb ágazataiba áramolhatnak. E dinamikus hatásokkal egyidejüleg romlik az alacsony hatékonyságú piaci szereplők helyzete, illetve a hatékony szereplők növelhetik kibocsátásukat. Mindez módot nyújthat a méretgazdaságossági előnyök kihasználására. 
2. ábra

Az egy főre jutó GDP növekedése Írország európai csatlakozása során (reálértékben, dollár)
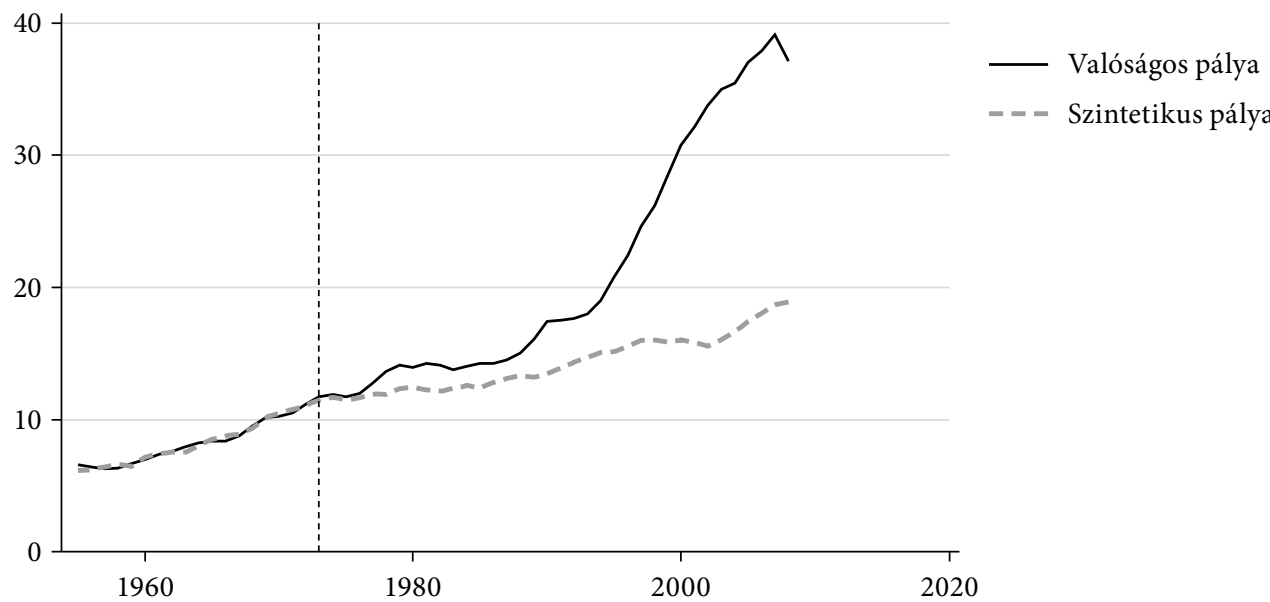

- - - Szintetikus pálya

Forrás: Campos és szerzőtársai [2014] 32. o. 1. ábra.

\section{Európai integráció és növekedési elmélet}

Az európai integráció akkumulációs hatása a gazdasági növekedés elméletének gondolatmenetén alapul. Valamely nemzetgazdaságban az egy före jutó jövedelem csak akkor növekedhet fenntartható módon, ha a dolgozók a fizikai, az emberi (benne a tudás-) tőke állandóan emelkedő állományával vannak ellátva. Következésképpen az európai integráció a növekedési ütemet a fizikai, az emberi (benne a tudás-) tőke akkumulációja révén befolyásolja.

Az európai integráció két alapvető mechanizmus révén gyakorol hatást a tőkeakkumulációra.

1. Az európai integráció növeli az európai gazdaság hatékonyságát, pozitív allokációs hatást fejt ki, emeli a kibocsátást, $\mathrm{s}$ - állandó beruházási arányt feltételezve is - növeli a beruházást. A több beruházás eredményeképpen nagyobb hosszú távú egyensúlyi tőkeállomány, következésképpen több egy före jutó egyensúlyi jövedelem alakul ki.

2. Az európai integráció eredményeképpen csökken a beruházási kockázat. Ez ceteris paribus ugyancsak növeli a beruházásokat. Annak eredményeképpen ugyancsak nő az egy dolgozóra jutó tőkeállomány és kibocsátás.

A középtávú növekedési többlet kulcsa az európai integrációban az indukált tőkeképződés. Az integráció által indukált beruházás vezérelte növekedés számos empirikus példával támasztható alá. (A beruházási boom s az általa előmozdított gyors GDPnövekedés példájaként idézhető a spanyol csatlakozás az 1980-as évek közepén vagy az észt belépés 2004-ben.) Az integráció arra ösztönzi a vállalatokat, hogy növeljék az egy dolgozóra jutó tőke szintjét. 
A hosszú távú növekedési hatásokat alátámasztó mechanizmus ugyanaz, mint a középtávú növekedési hatások esetében. Ám - minthogy a tudástőke esetében nem érvényesül csökkenő megtérülés - a tudásba történő $(\mathrm{K}+\mathrm{F}$-) befektetés emelkedése elvileg az egyébként lehetségesnél magasabb növekedési ütemet eredményezhet.

A bemutatott mechanizmus ellenére létezik olyan álláspont, amely szerint az európai integráció hosszú távú növekedési hatásait nehéz bizonyítani (Deardorff-Stern [2002], Baldwin-Wyplosz [2012]). Ugyanakkor más empirikus vizsgálatok szerint az EU-tagság hosszú távon pozitív és aszimmetrikus hatást gyakorol a gazdasági növekedésre (Crespo-Cuarezma és szerzötársai [2007]). A modellben a nyitottság kontrollváltozóként szerepel, ezért a regionális integráció növekedési hatása elkülöníthető az intenzívebb kereskedelem hatásaitól, és a technológiai tudás tagországok közötti jobb átadásához kapcsolódik. Az eredmények tehát az endogén növekedési elmélet újabb alátámasztását nyújtják. A kutatás szerint a viszonylag kevésbé fejlett országok tesznek szert a legnagyobb haszonra a regionális integráció által nyújtott szélesebb technológiai rendszerhez történő csatlakozásból. Vagyis az EU-tagság hosszú távon pozitívés aszimmetrikus hatást gyakorol a gazdasági növekedésre.

Ám nem a kereskedelem és a technológia az egyetlen tényező az EU-tagsághoz kapcsolódó növekedési többlet (bónusz) magyarázatában. A további lehetséges tényezők - egyebek mellett - a következők: a választékgazdaságosság (economies of scope) néven is tárgyalt változatossági elönyök, az intézményrendszer hatékonyságának növekedése, a liberalizáció nyomán a kormányzatok méretének csökkenése, a monetáris integráció. A jelzett bizonytalanság ellenére a neoklasszikus növekedési modellnek a hosszú távú növekedési hatások hiányára vonatkozó feltételezése elvethető. Az európai integráció növekedési hatásai, mindenekelőtt a tudás tovagyürüzése hosszabb távon is müködik. Egyidejüleg az európai integráció a konvergencia lényeges hajtóereje.

Az integráció tehát nemcsak a kibocsátás szintjére van hatással, hanem a jövedelem növekedési rátáját is pozitívan befolyásolja. Középtávon az integráció gyorsabb növekedést tesz lehetővé, mivel a magasabb jövedelem több megtakarítást és beruházást, valamint nagyobb tőkeállományt eredményez. A legújabb növekedési elméletek szerint az integráció állandóan magasabb növekedési ütemet biztosíthat a tagállamok számára az integráció nélküli helyzethez képest (lásd például Rivera-Batiz-Romer [1991], Grossman-Helpman [1994a], [1994b], Coe-Helpman [1995]). ${ }^{5}$

\section{Európai növekedési modell}

Az eddigi elemzések alapján megfogalmazhatók a 20. század második felében az integráció keretei között kialakult európai növekedési modell fö sajátosságai. E jellemzők mindenekelőtt a következők.

\footnotetext{
${ }^{5}$ Campos-Coricelli [2015] a kereskedelem és a nyitottság termelékenységi hatásait vizsgálta az Egyesült Királyság EU-tagságával összefüggésben. Az EU-tagállamokkal folytatott, nagyrészt iparágon belüli kereskedelem által generált permanens termelékenységi nyereség alapvetően a megnövekedett versenyen és a technológiai innováción alapult.
} 
1. Kereskedelmi integráció, nagyfokú nyitottság. Az európai integráció mindenekelőtt a kereskedelem akadályait bontotta le - a vámunió megteremtésétől egészen a belső piac kiépítéséig (intézményi nyitottság). Mindezek következtében az európai gazdaságok integráltabbak, mint bármely más régió a világgazdaságban. A külkereskedelem aránya, azaz a reálgazdasági nyitottság foka nagyobb, mint a világgazdaság más térségeiben (a Távol-Keletet is beleértve). A kereskedelem nagy aránya - az egységes piac kereskedelemteremtő hatásain túl - az európai nemzetgazdaságok viszonylag kisebb méretével is magyarázható. A szolgáltatások belső piaca azonban - szabályozási tényezőkkel is összefüggésben - még nem bontakozott ki olyan mértékben, mint az áruk kereskedelme.

2. Pénzügyi integráció, robusztus tőkeáramlás. A közös, majd az egységes piac kiépülésével párhuzamosan rendkívül nagy arányúvá vált a tőkeáramlás. ${ }^{6}$ Európában a tőkeáramlás jellemzően „lefelé”, a kevésbé fejlett országokba irányul (Lucas [1990]). A világgazdaság más térségeiben a tőkeáramlás gyakran szokatlan irányú: a tőke „felfelé”, a szegényebb országokból a gazdagabb országokba áramlik (Prasad és szerzőtársai [2007]). Európán kívül a tőke gyakran áramlik lassan növekvő gazdaságokba. Számos feltörekvő piacgazdaságban csak a folyó fizetési mérleg többletének emelkedése esetén nő a jövedelem, ${ }^{7}$ Európában viszont az elmúlt évtizedekben a tőke a gyorsabban növekvő gazdaságba áramlott.

3. A termelékenység gyors javulása. Az európai integrációban a termelékenység évtizedeken át dinamikusan nőtt, $s$ ennek meghatározó szerepe volt a - jelentős részben technológiai adaptáción alapuló - felzárkózási növekedésben. Az európai országok évtizedeken át csökkentették a világgazdaság legfejlettebb gazdaságával, az Egyesült Államokkal szemben fennálló termelékenységi rést. A tőkeintenzitás és a teljes tényezőtermelékenység növekedése folyamatos lökést adott a munka termelékenységének emelkedéséhez.

4. Növekedési bónusz. Az európai integráció emeli a tagállamok gazdasági növekedésének ütemét. ${ }^{8}$ A növekedési ütemet elsősorban a fizikai, az emberi (a tudás-) tőke akkumulációjának előmozdítása révén befolyásolja. Növeli az európai gazdaság hatékonyságát, pozitív allokációs hatást eredményez, emeli a kibocsátást, csökkenti a kockázatot, $\mathrm{s}$ - állandó beruházási arányt feltételezve is - növeli a beruházást. A több beruházás eredményeképpen nö a hosszú távú egyensúlyi tőkeállomány, következésképpen magasabb egy före jutó egyensúlyi jövedelem alakul ki. A hosszú távú növekedési hatásokat alátámasztó mechanizmus hasonló. Ám - minthogy a tudástőke esetében nem csökkenő a megtérülés - a tudásba történő befektetés $(\mathrm{K}+\mathrm{F})$ emelkedése elvileg a növekedési ráta állandó emelkedéséhez vezethet.

Az EU-tagsághoz kapcsolódó növekedési többlet (bónusz) magyarázatában további lehetséges tényezök a következők: az intézményrendszer hatékonyságának növekedése, a liberalizáció nyomán a kormányzatok méretének csökkenése, a monetáris

\footnotetext{
${ }^{6}$ A kibocsátás arányában a legnagyobb tőkeáramlás az elmúlt évtizedekben az EU-tagállamok között mutatható ki (Gill-Raiser [2011]).

${ }^{7}$ Ezt az „allokációs rejtélyt” először Gourinchas-Jeanne [2007] írta le.

${ }^{8}$ Berend T. Ivánt idézve: „A kivételes gazdasági növekedés és integráció következtében Európa ismét gazdasági szuperhatalom lett.” (Berend ([2008] 306. o.)
} 
integráció. Az európai integráció növekedési hatásai - mindenekelőtt a tudás tovagyürüzése - hosszabb távon is működnek. A legújabb növekedési elméletek szerint az integráció állandóan magasabb növekedési ütemet biztosíthat a tagállamok számára az integráció nélküli helyzethez képest.

5. Erőteljes konvergencia. A gazdasági integráció a felzárkózási növekedés révén a világ többi részénél gyorsabb jövedelemkonvergenciát eredményezett. Az alacsonyabb kezdeti jövedelemmel rendelkező európai országokban magasabb volt a gazdasági növekedés üteme, mint a fejlettebbek esetében. Kelet-Ázsiában e hasonló folyamat jóval kevésbé volt erőteljes, mint Európában (Gill-Raiser [2011]). E konvergenciafolyamat meghatározó tényezője a kereskedelem integrációja és a robusztus tőkeáramlás volt. Továbbá az érintett európai gazdaságok évtizedeken át csökkentették az Egyesült Államokkal szemben az egy före jutó jövedelemben mutatkozó elmaradásukat, azaz a felzárkózási növekedés nem csak a kontinensen belül érvényesült.

A reálkonvergencia Európában feltétele a közös, majd az egységes piac zavartalan müködésének. A négy alapszabadság akkor érvényesülhet, ha megvalósul a konvergencia. (Annak hiányában ugyanis tömeges belső migrációs folyamatok indulnának meg.) Valójában a gazdasági és monetáris unió is feltételezi - a meghirdetett nominális kritériumokon túl - a reálkonvergenciát. E kohéziós mechanizmus alátámasztását célozza az európai szolidaritás. Az EU strukturális politikájának fö célja az elmaradt térségek felzárkóztatásának előmozdítása. Az ezzel kapcsolatos tapasztalatok a különböző tagállamokban eltérők: sikeresebbek voltak a vezető és az elmaradó térségek integrációját az infrastruktúra fejlesztése révén előmozdító megoldások, amelyek regionális konvergenciát eredményeztek. Ám a gazdasági tevékenység kiterjesztésére, illetve a munkahelyek áthelyezésére irányuló széles körű térségi intervenciók kevésbé bizonyultak sikeresnek (World Bank [2009]). A konvergenciát előmozdító mechanizmus Európában az elmúlt évtizedekben elsősorban a piacra épült, a szolidaritásra épített nem piaci mechanizmusok összehasonlíthatatlanul szerényebb szerepet játszottak.

6. Társadalmi és környezeti felelősség, szolidaritás. Az európai gazdaság fejlödését egyúttal a szociális biztonság erősödése kísérte. A társadalmi ellátórendszerek széles körben kiépültek, s magas színvonalú szolgáltatásokat nyújtanak. Európában a jövedelmi különbségek mérsékeltebbek, mint a tengerentúlon, de a nagy ellátórendszereket nagy feladatok elé állítják a demográfiai változások, az idősödés, a növekvő strukturális munkanélküliség, illetve a közkiadások mérséklése, a költségvetési konszolidáció igénye. Az európai gazdaságok a versenytársaiknál nagyobb figyelmet fordítottak a környezeti kihívások kezelésére. ${ }^{9}$ A szigorúbb szociális és környezeti normák jelentős részben európai uniós irányelveken alapulnak, de a nagyrészt nemzeti és uniós szabályok bonyolult peremfeltételeket, bizonyos értelemben versenyhátrányt jelentenek a vállalkozások számára a globális piacon folytatott versenyben.

7. Európai kormányzás. A nagyobb társadalmi és környezeti felelösség az újraelosztást növelte az európai államokban. Emiatt a versenytársakénál magasabbak az elvonások, illetve egyes országokban tartós és jelentős az állami túlköltekezés, $\mathrm{s}$

\footnotetext{
${ }^{9}$ Például az európai országok nyújtják a legjobb teljesítményt az üvegházhatású gázok kibocsátásának csökkentésében.
} 
korábban példa nélküli arányú államadósságok halmozódtak fel. Ugyanakkor erőteljes szupranacionális szabályozás és kormányzás valósult meg. A közösségi módszer alkalmazása példátlan mértékű integrációhoz vezetett e területen is. ${ }^{10} \mathrm{Az}$ intézményesített szupranacionalitáshoz azonban nem kapcsolódik költségvetési föderalizmus. A közös költségvetés hosszabb távon is csak a tagállamok GDP-jének 1 százaléka körüli nagyságrendü. Az erőteljes integráció ellenére is jelentősek az eltérések az egyes országok intézményeinek minőségében.

\section{Az európai növekedési modell változásai - erózió és válság}

\section{A potenciális növekedés alakulása ${ }^{11}$}

Az EU15 országaiban ${ }^{12}$ a potenciális növekedési ütem az 1980-as évektől kedvezőbben alakult, mint ami az 1973 utáni válságos éveket jellemezte. A „nagy mérséklődés” (great moderation) időszaka egészen a 2008-ban kezdődött nagy válságig (great recession) tartott. Ám 1990-től a potenciális növekedés üteme fokozatosan és folyamatosan mérséklődött.

A látens, majd egyre inkább nyílt erózió nyomán a potenciális kibocsátás évi dinamikája 2005-től már 2 százalék alá került (4. ábra). 2000 és 2008 között az Európai Unióban

- felére csökkent a potenciális növekedési ütem;

- döntő tényező volt a munkatermelékenység dinamikájának a mérséklődése;

- a korábbi negyedére csökkent a teljes tényezőtermelékenység (TFP) hozzájárulása;

- ugyanakkor a munkatényező hatása 1996 és 2007 között viszonylag nagy volt.

2008-tól, a nagy válság kezdetétől (great recession) a potenciális növekedés dinamikája drámaian csökkent:

- nulla körüli, majd tartósan alacsony maradt a teljes tényezőtermelékenység hozzájárulása,

- példátlanul alacsony lett a tőketényező hatása,

- negatív előjelü, majd tartósan alacsony maradt a munkatényező hatása.

${ }^{10}$ Ennek jellemzésére a többszintű kormányzás (multilevel governance) fogalmát használják.

${ }^{11} \mathrm{Az}$ alkalmazott növekedési számviteli módszer áttekintését a 3. ábra tartalmazza.

${ }^{12} \mathrm{Az}$ EU15 országokat három csoportra osztottuk:

- Az alapító hatok (A6) közé az Európai Gazdasági Közösséget (EGK) 1958-ban alapító hat ország (Németország, Franciaország, Olaszország, Belgium, Hollandia, Luxemburg) került. Ezek az országok a kontinentális európai modellt képviselik.

- „Új” tagországok (U6) az Európai Közösségekhez, illetve az Európai Unióhoz 1973-ban, illetve 1995-ben csatlakozott fejlettebb országok: az „angolszász” modellhez sorolható Egyesült Királyság és Îrország, illetve a „skandináv” modellbe tartozó Dánia, Finnország és Svédország, végül Ausztria.

- Mediterrán tagállamok (M3) az 1981-ben csatlakozott Görögország, illetve az 1986-tól tag ibériai országok (Spanyolország és Portugália). E legutóbbi csoport tagjai a mediterrán modellbe tartoznak.

Az itt következő számítások alapját az EU Tanácsa Gazdaságpolitikai Bizottsága (Economic Policy Committee, EPC) Kibocsátási Rés Munkacsoportjának (Output Gap Working Group, OGWG) paneladatai képezték. A nyers adatok csoportosítása, feldolgozása és elemzése a szerző munkája. 
3. ábra

A növekedési számvitel termelésifüggvény-alapú megközelítése

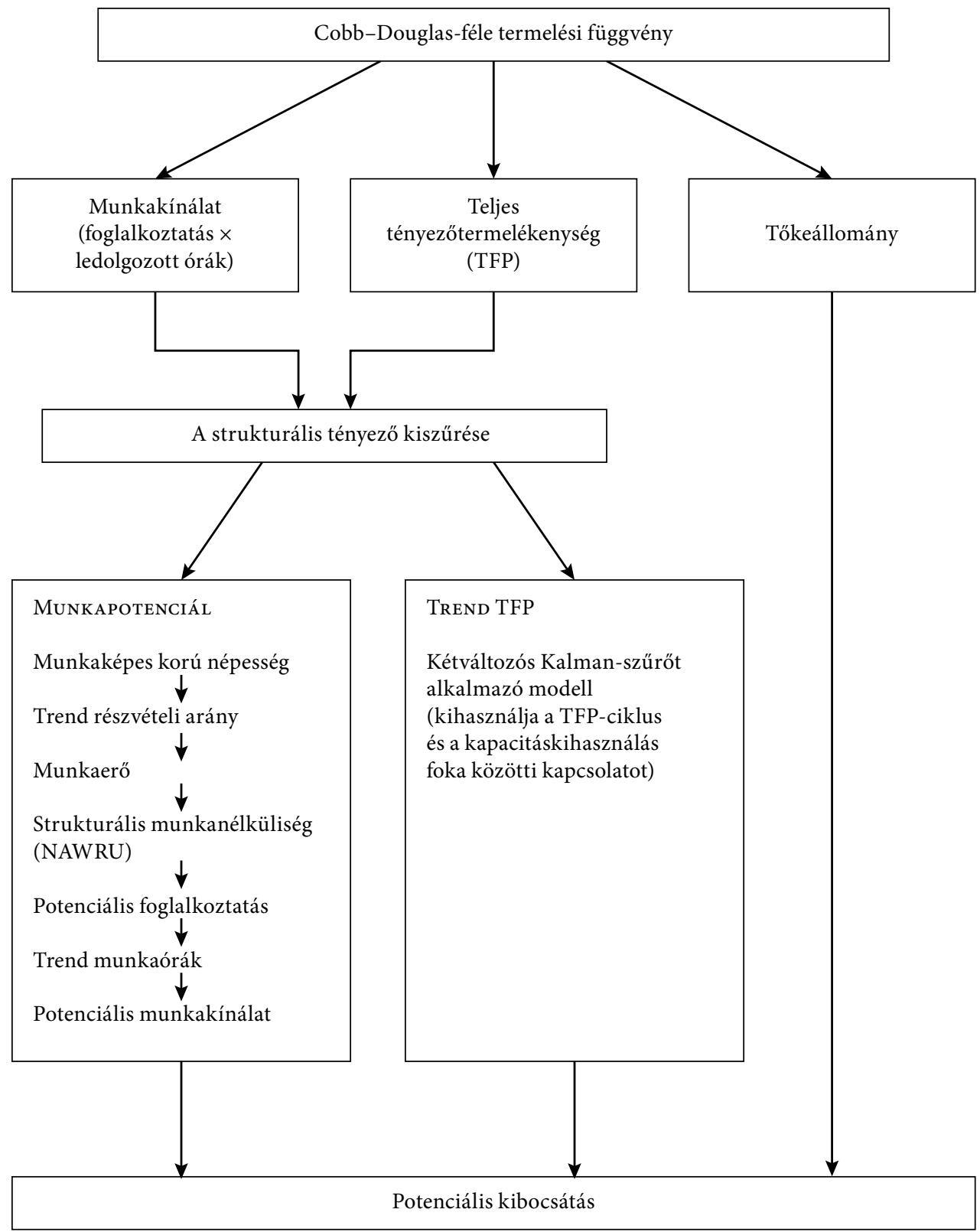

Mindeme tényezők miatt a potenciális növekedés dinamikája mindeddig példátlanul alacsony szintre süllyedt, $s$ a kilábalás után is csak a válság előtti - már lecsökkent szint mintegy felét éri el. E lényeges lassulás strukturális törést jelent az európai növekedési potenciál dinamikájában. Az elvégzett szimulációk szerint annak üteme csak 2017-től emelkedik ismét évi 1 százalék fölé az EU15 átlagában. 
4. ábra

A potenciális növekedés hosszú távú alakulása az EU15 országaiban (százalék)

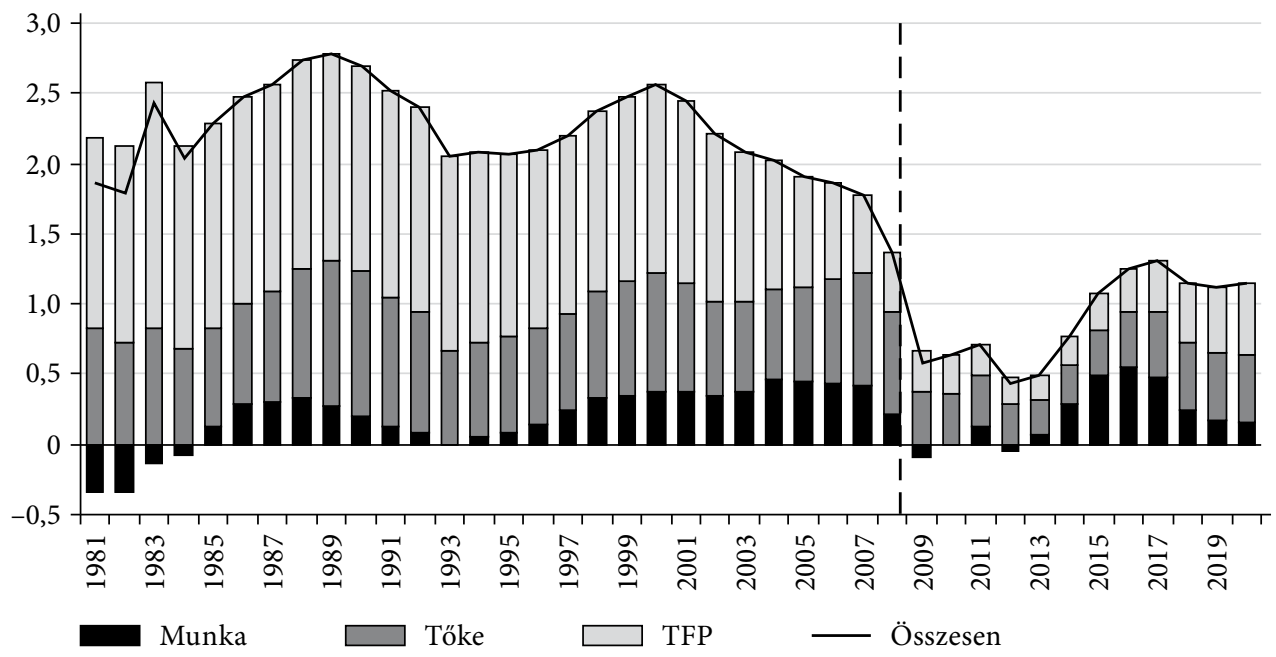

Forrás: saját számítás.

5. ábra

A potenciális növekedés hosszú távú alakulása az U6 országcsoportban (százalék)

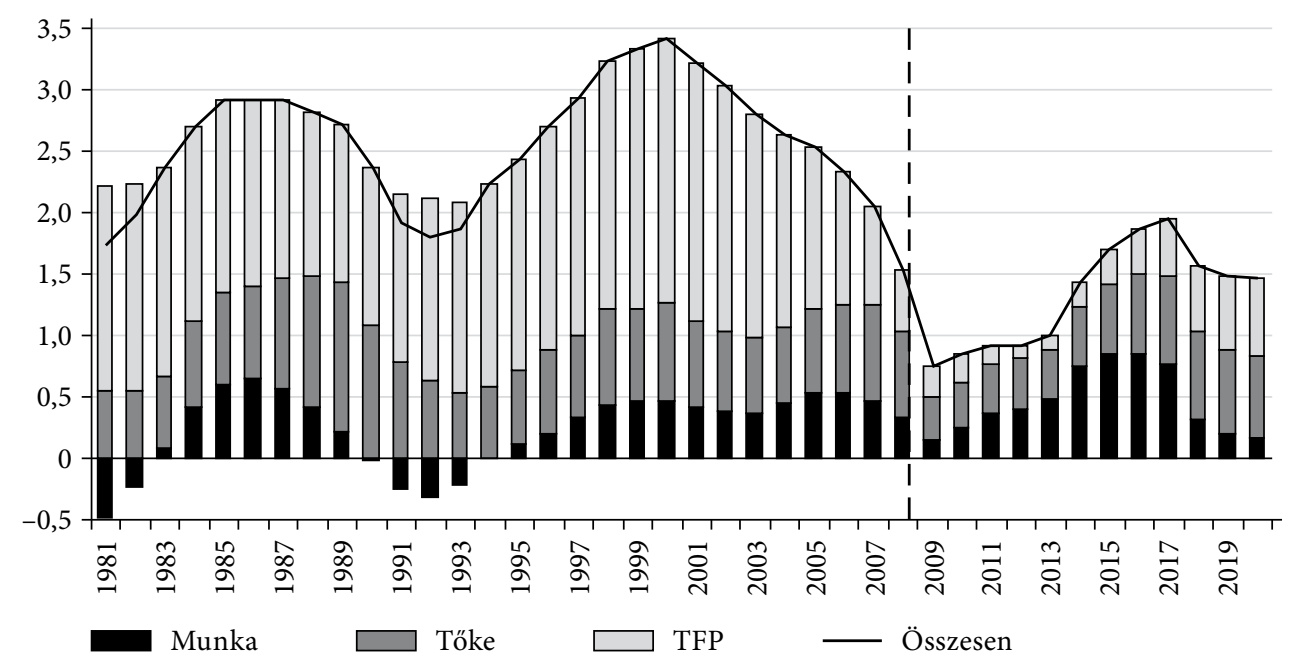

U6: Ausztria, Dánia, Egyesült Királyság, Finnország, Írország és Svédország.

Forrás: saját számítás.

Ugyanakkor jelentős eltérések mutatkoznak az EU15 fö országcsoportjai között a növekedési potenciál alakulásában. Az „új” fejlett tagokat (U6) a „nagy mérséklődés" időszakában kiemelkedő növekedési potenciál jellemezte (5. ábra). Kiemelkedő a teljes tényezőtermelékenység, a munka és tőke nagymértékű hozzájárulása képezték ennek az alapját. A 2000-es évek elejétől fokozatos, majd 
2008 után erős lassulás mutatkozott. A kilábalás során ismét megközelítették a válság előtti dinamikát.

A mediterrán tagállamok (M3) a csatlakozás után magas növekedési potenciált értek el, amiben a munka- és a tőketényező hatása dominált, de a teljes tényezőtermelékenység hozzájárulása az 1980-as évek végétől csökkenő tendenciát mutatott.

A 2008-as „nagy válság” e mediterrán tagállamokban drámai hatásokkal járt: átmenetileg negatív növekedési potenciál alakult ki. A munkatényező hatásának előjele a válság és az elhúzódó kilábalás időszakában végig negatív volt. A teljes tényezőtermelékenység hozzájárulása egyes években negatív előjelűvé vált, a tőketényezőé pedig nulla értékre csökkent (6. ábra). Mindez strukturális törést mutat az elöző évtizedekhez képest.

\section{6. ábra}

A potenciális növekedés hosszú távú alakulása az M3 országcsoportban (százalék)

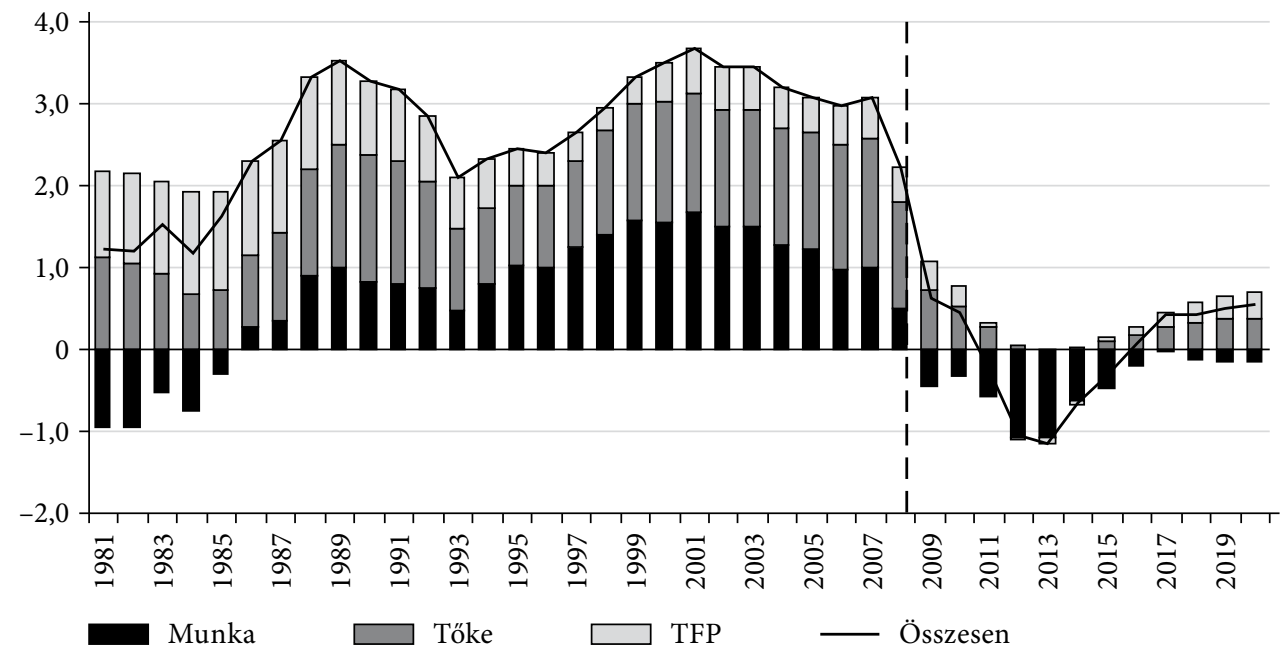

M3: Görögország, Portugália, Spanyolország.

Forrás: saját számítás.

Az egyes tagállamok, illetve csoportjaik helyzetében igen jelentős eltérések mutatkoznak a válság és a kilábalás időszakában. Az A6 és M3 esetében nagyon alacsony a termelékenység hozzájárulása a potenciális növekedéshez. Növekvő divergencia mutatkozik a teljes tényezőtermelékenységben. A strukturális munkanélküliség tekintetében pedig drámai eltérések alakultak ki a fejlett magországok és a mediterrán periféria tagállamai között.

Az Egyesült Államok potenciális növekedési üteme a vizsgált időszakban mindvégig meghaladta az EU15-ét. Következésképpen a vizsgált időszakban az EU-ban már nem volt felzárkózási növekedés. Sőt valójában tartós divergencia mutatkozott, illetve mutatkozik (7. ábra).

Az amerikai növekedési potenciálban a munkatényező hozzájárulása az ezredfordulóig magas volt, majd erőteljesen csökkent. A munka termelékenységének 


\section{7. ábra}

A potenciális növekedés hosszú távú alakulása az Egyesült Államokban (százalék)

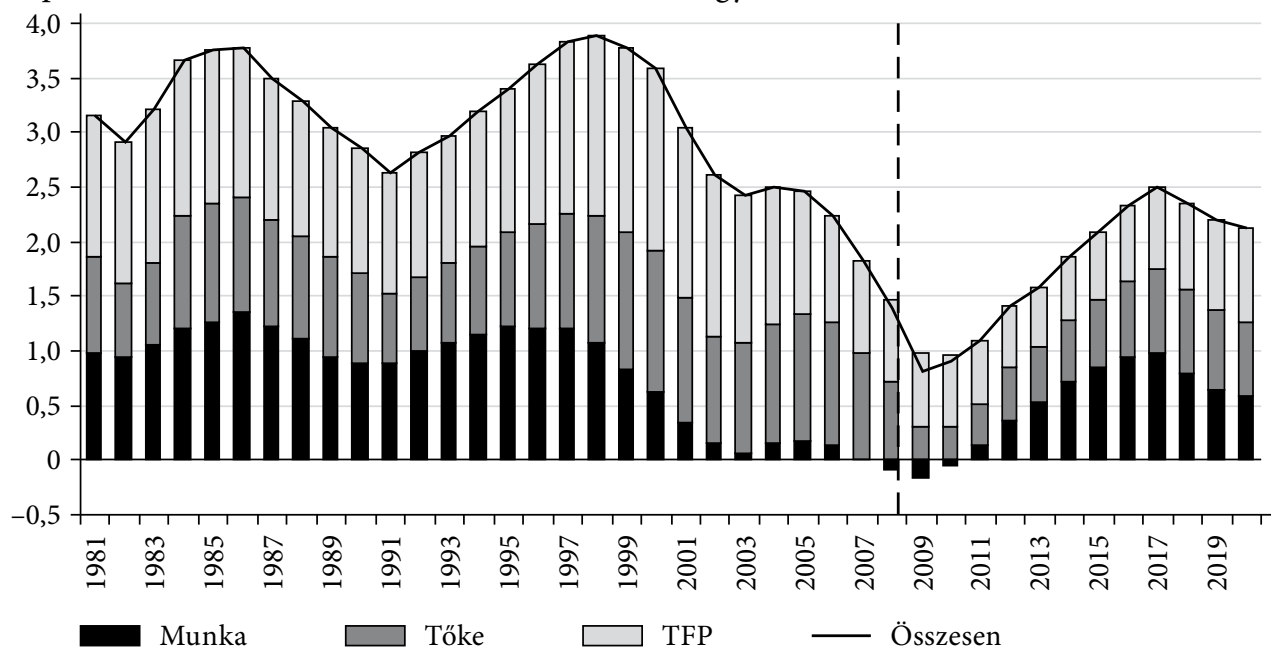

Forrás: saját számítás.

8. ábra

A potenciális növekedés hosszú távú alakulása az EU15-ben és az Egyesült Államokban (százalék)

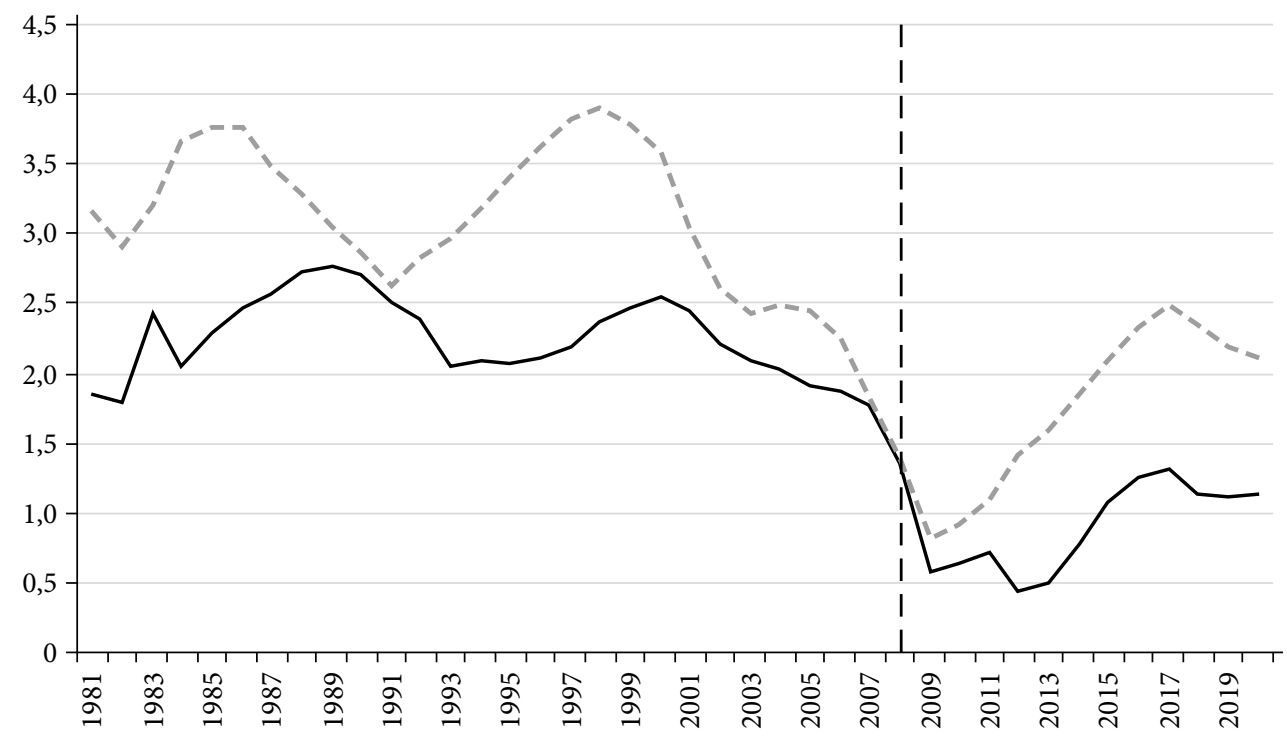

EU15

- - - Egyesült Államok

Forrás: saját számítás. 
hozzájárulása 1993-tól meghaladja az EU15-ét, jelenleg annak a kétszerese. A teljes tényezőtermelékenység hozzájárulása 1995-től végig magasabb, mint az EU15-ben (8. ábra). A 2008-as válság után gyors kilábalás jellemezte az Egyesült Államokat, s a válság elötti növekedési potenciál nagyjából helyreállt (9. ábra).

\section{9. ábra}

A potenciális növekedés hosszú távú alakulása az EU15-ben, annak egyes országcsoportjaiban és az Egyesült Államokban (százalék)

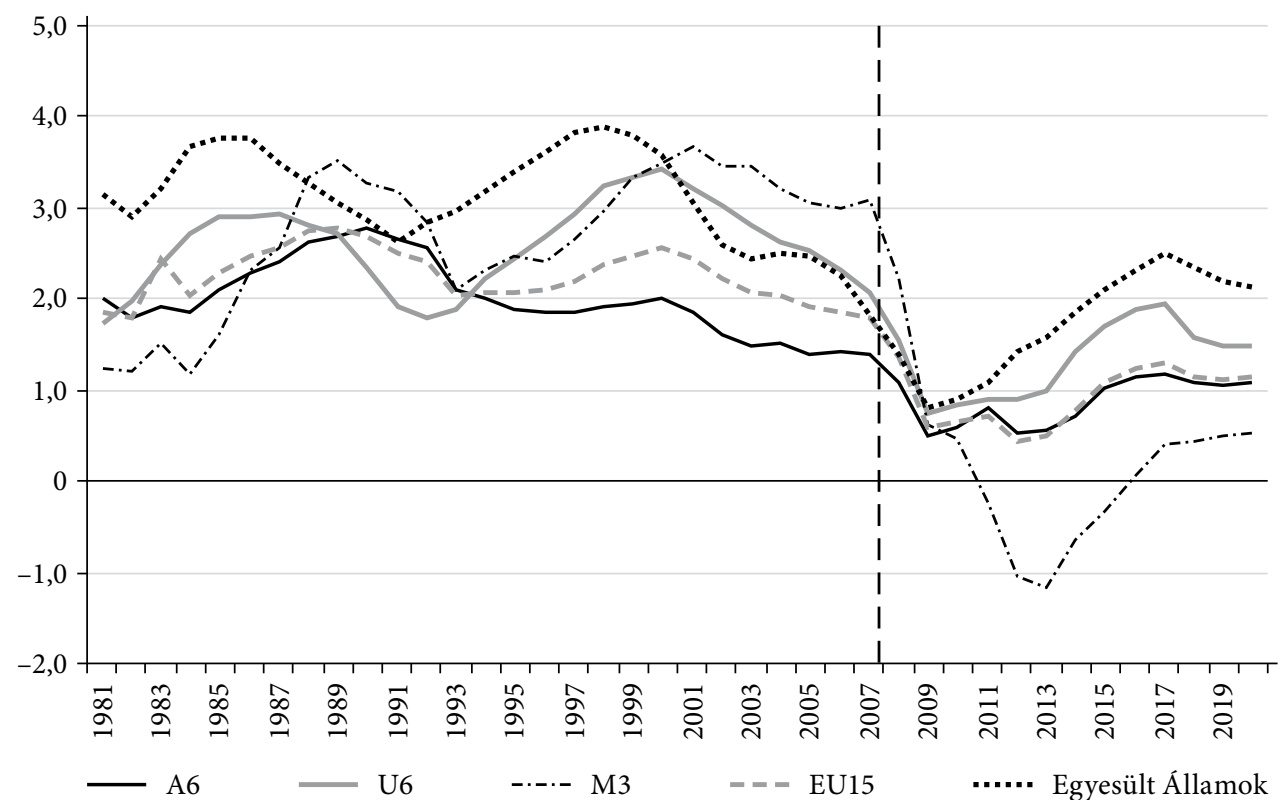

Forrás: saját számítás.

Az eddigi elemzés alapján összefoglalhatók az egyes vizsgált országcsoportok növekedési modelljeinek fö jellemzői.

Az EU15 potenciális növekedési üteme 2001-töl folyamatosan csökkent. E csökkenés a munkatermelékenység alakulásával magyarázható. (A munkatényező hozzájárulása 1995 és 2008 között pozitív előjelű volt.) A munkatermelékenység növekedési üteme 1993-tól folyamatosan mérséklödött. Minthogy a tőketényező hozzájárulása a potenciális növekedéshez 2009-ig nem csökkent lényegesen (végig évi 0,7-0,9 százalék között ingadozott), a munkatermelékenység csökkenésének strukturális tényezője a teljes tényezőtermelékenység kedvezőtlen alakulása volt. (Annak évi aránya három évtized alatt nagyjából a harmadára csökkent. Az EU15 növekedési modelljét az 4. ábra foglalta össze.)

Mindezek alapján megállapítható, hogy az amerikai növekedési modell a vizsgált három és fél évtizedes időszakban az EU15 átlagánál nagyobb növekedési dinamikát tartalmazott (10. ábra). 
10. ábra

A teljes tényezőtermelékenység hosszú távú alakulása az EU15-ben és az Egyesült Államokban

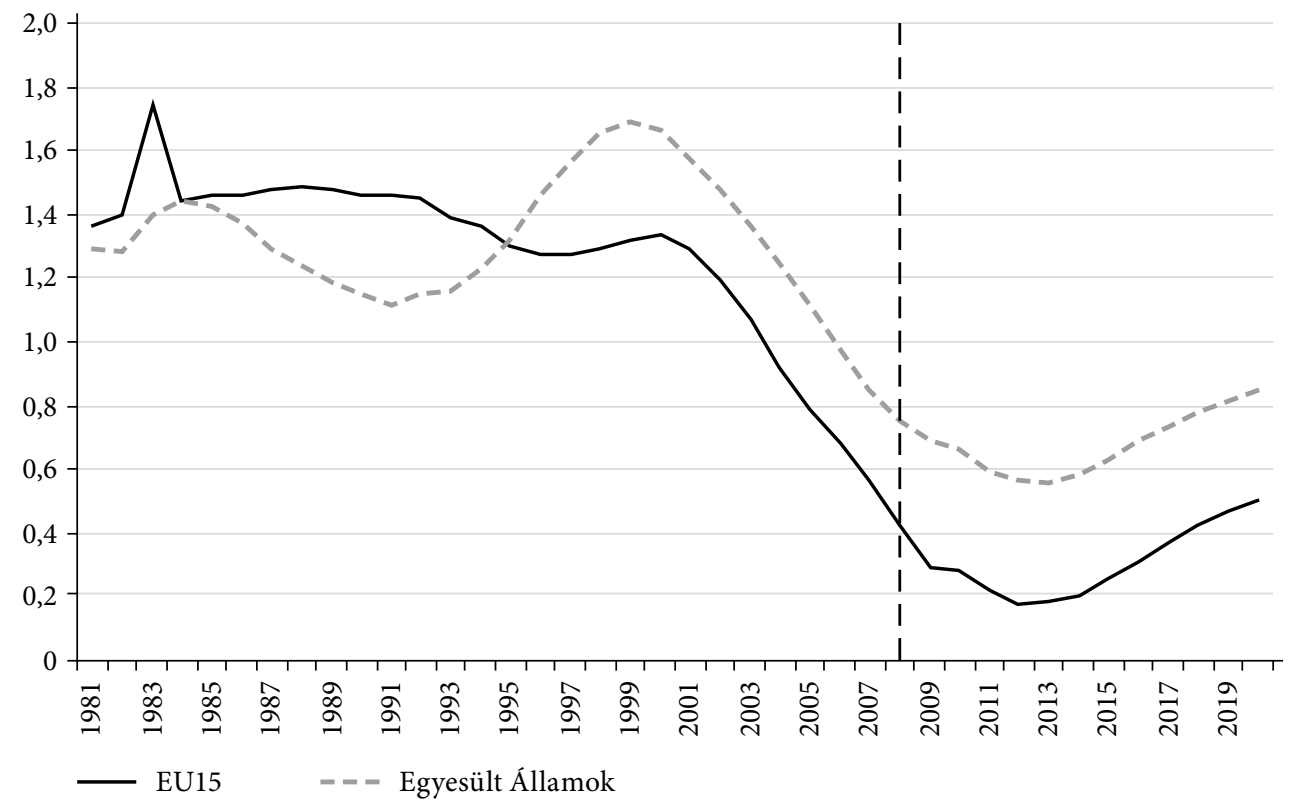

Forrás: saját számítás.

Felzárkózási potenciál a vizsgált időszakban az EU15 átlagát tekintve nem volt kimutatható, s ugyanez vonatkozik az A6-országokra. Az M3 országai potenciális növekedési ütemüket tekintve egyes időszakokban (1988-1992, 2000-2009) némileg csökkentették a hatalmas különbséget, ám a válság kezdetétől úgyszólván megállíthatatlan módon leszakadtak a magasabb dinamizmust teljesítő országcsoportoktól. Az U6 országaiban a potenciális növekedés viszont nagyjából az Egyesült Államokkal párhuzamosan alakult. A 2000-2008 közötti időszakban pedig az U6 potenciális kibocsátása gyorsabban bővült, mint az amerikai. Az U6 növekedési teljesítményének meghatározó tényezője a munkatermelékenység, illetve annak meghatározói között a teljes tényezőtermelékenység folyamatos dinamikája. E tényezők növekedési üteme egészen 2006-ig az U6-ban meghaladta az Egyesült Államokét (11. ábra).

Ugyanakkor az Egyesült Államok már a válság előtt az EU tagállamainál robusztusabb strukturális jellemzőkkel (mindenekelőtt szignifikáns módon kedvezőbb teljes tényezőtermelékenységgel) rendelkezett. Jelenleg előre jelezhető demográfiai és teljes tényezőtermelékenységgel kapcsolatos irányzatai, várható beruházási és termelékenységi dinamikája lényegesen kedvezőbb, mint az EU15, illetve az euróövezet tagállamaié. Mindezek miatt nem meglepő, hogy az Egyesült Államok esetében nagyjából helyreállhat a növekedési potenciál válság előtti dinamikája, míg a vizsgált európai országokban - változatlan politikát feltételezve - a felére csökkenhet. 
11. ábra

A teljes tényezőtermelékenység hosszú távú alakulása az EU15-ben, annak egyes országcsoportjaiban és az Egyesült Államokban

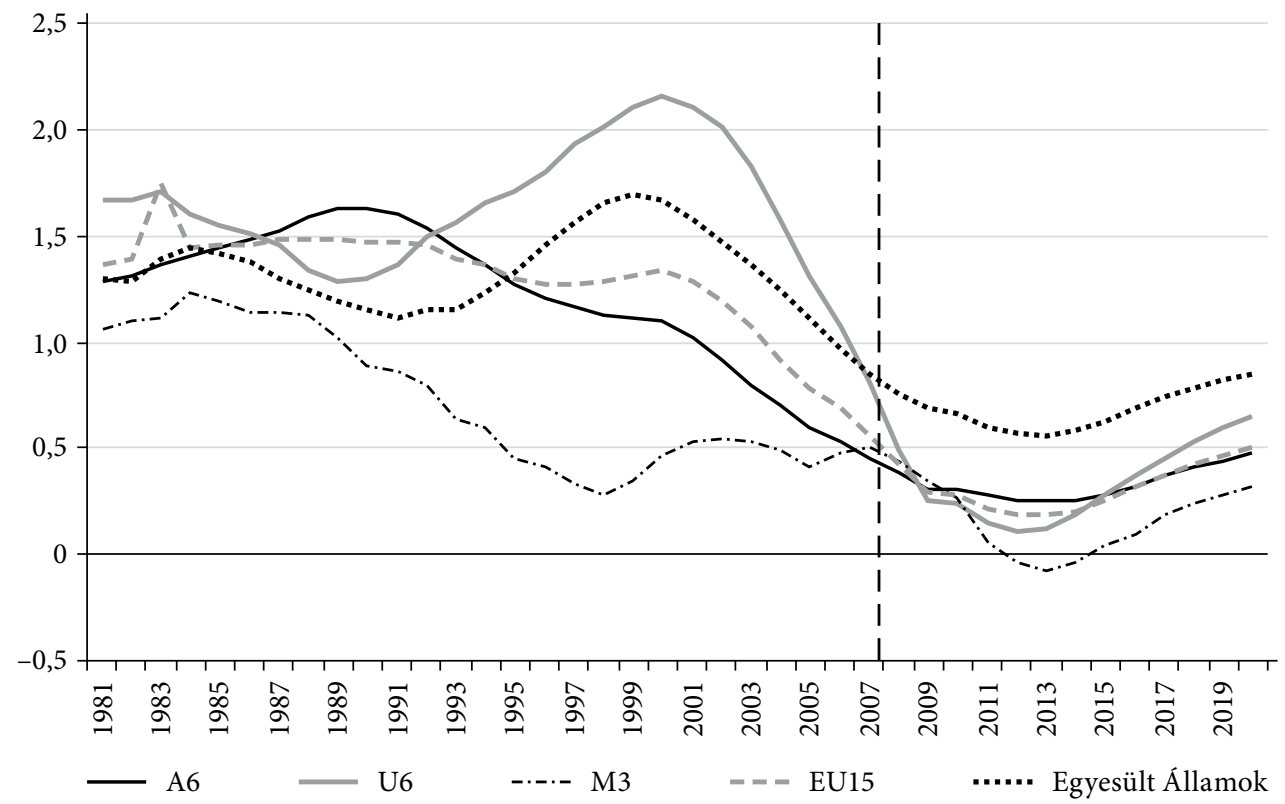

Forrás: saját számítás.

Termelékenységi rés az Európai Unió és az Egyesült Államok között

Az EU-tagállamok termelékenységének felzárkózása (azaz az Egyesült Államokénál gyorsabb növekedése) fokozatos mérséklődés után az 1990-es évek közepén megtört, majd dinamikája egyre inkább elmaradt fö versenytársáétól. Az elmúlt két évtizedben az EU15 országainak többségében más fejlett OECD-országokhoz - mindenekelőtt az Egyesült Államokhoz - képest a termelékenység dinamikája mérséklödött. E termelékenységi rés döntő része nem a beruházásokkal magyarázható. (Bár az Egyesült Államokban a beruházások az európainál nagyobb mértékben összpontosultak az infokommunikációs területre.) A jelzett tendencia döntően a teljes tényezőtermelékenység (TFP) változásával magyarázható.

A legutóbbi évtizedekben a fejlett gazdaságokban a növekedési lehetőségek egyre inkább a szolgáltató ágazatokban és az infokommunikációs technológiák (IKT) diffúziójában koncentrálódnak. Az új korszakban döntő tényezővé vált a munka- és a termékpiacok rugalmas alkalmazkodása, illetve az immateriális (intangible) beruházások növekedése, szemben a fizikai tőke masszív beruházásával (Nicoletti-Scarpetta [2005], Timmer és szerzötársai [2010]).

A munkatermelékenység országok közötti eltérése túlnyomórészt a teljes tényezőtermelékenységben megmutatkozó eltéréseket tükrözi (Pichelmann, szerk. [2007] 
41-66. o.). Az eltérésekben - föleg az 1990-es évek második felében - az infokommunikációs beruházások is szerepet játszottak. Az EU és az Egyesült Államok közötti termelékenységi rés fennmaradásában az egy dolgozóra jutó tőke növekedése jóval kisebb szerepet játszik, mint a teljes tényezőtermelékenység eltérő dinamikája. Ugyanakkor a tőkeszolgálat hozzájárulásának további felbontása szerint lényeges eltolódás mutatkozik az Egyesült Államokban az infokommunikációval összefüggö tőke javára, míg ilyen mértékủ hasonló irányzat nem érvényesül Európában. Az Egyesült Államok és az EU közötti TFP-rés csaknem teljes egésze csekély számú iparágban összpontosul: az elektronikai berendezések előállítása, a nagy- és a kiskereskedelem, az ingatlan- és egyéb üzleti szolgáltatások, illetve a pénzügyi szolgáltatások területén (Havik és szerzőtársai [2008]). A fejlődési különbség fő tényezőinek elkülönítése hozzásegíthet a potenciálisan legnagyobb hatású politikák és szakpolitikai intézkedések kidolgozásához, illetve meghozatalához.

A schumpeteri „alkotó romboláson” alapuló növekedési elméletek alkalmasnak tünnek az EU növekedési teljesítményének magyarázatára (lásd például AghionHowitt [2005a]). A technológia élvonalában lévő vagy ahhoz közel álló gazdaságok növekedésének motorja az innováció, amely meghatározó szerepet játszik a teljes tényezőtermelékenység alakulásában. Az innovációs ráta az innovációs forrásoktól ( $\mathrm{K}+\mathrm{F}$, illetve az emberi tőke), valamint a meglévő tudásállománytól (stock of existing knowledge) függ (a tudás tovagyürüzése - knowledge spillovers). A gazdasági növekedés üteme nemcsak az innovációs rátának, hanem a korszerủ technológiák terjedési sebességének is függvénye. A technológiai élmezőnyhöz közel álló országokban a teljes tényezőtermelékenység növekedésében meghatározó jelentőségü az új technológiák alkalmazása, a „követő” országokban pedig az „élmezőnyben" már alkalmazott technológiák bevezetése.

Az intézmények és a szakpolitikák kulcsszerepet töltenek be az országok innovációs versenyében. A követő országok a meglévő technológiák költséghatékony adaptációját előmozdító intézmények és szakpolitikák révén érhetnek el előnyöket. $\mathrm{Az}$ élmezőny országaiban pedig a magasabb szintü oktatást és $\mathrm{K}+\mathrm{F}$-et, a kockázatos projektek iránt is nyitott pénzpiacokat, a müködő, illetve az újonnan piacra lépő vállalatok rugalmas müködését segítő (azon belül azok közterhekkel történő túlzott terhelését elkerülö) szakpolitika a meghatározó.

A teljes tényezőtermelékenység növekedése az 1995 utáni időszakban egyre erősebben az innovációval és a technológiai élmezőnybe tartozó országokból történő tovagyürüzéssel áll összefüggésben. Az európai unióbeli infokommunikációs technológiákat előállító feldolgozóipari ágazatok elsősorban a K+F-intenzitás területén maradnak el az egyesült államokbeli hasonló ágazatoktól (Havik és szerzőtársai [2008]). A kis- és nagykereskedelmi ágazatok termelékenységnövekedésének divergenciája ciklikus tényezőkkel és a méretgazdaságosság jobb kihasználásával magyarázható. A hálózatos iparágak területén az Európai Unió kedvezőbb teljesítményét döntően az elmúlt két évtizedben megvalósuló deregulációs folyamatok magyarázzák.

A termelékenységi különbségek fő okai a termékpiacok müködésének eltéréseiben, az Egyesült Államokban intenzívebb versenyviszonyokban, illetve az európai 
termékpiacok túlszabályozásában találhatók. Lényegesek az innovatív szektorok adminisztratív és pénzügyi belépési korlátai.

Bonyolult összefüggés áll fenn az ár-költség-rések és az innováció között. Az árköltség-rés a végtermékeket előállító ágazatokban a verseny (-hiány) indikátorának tekinthető, amelynek csökkentése növeli a termelékenységet. Ám az innovatív ágazatokban jóval bonyolultabb az árrések értelmezése, hiszen e szektorokban éppen az innovációs járadék jelenik meg ilyen résként.

A termelékenység és a tudásba történő beruházás különbségeit magyarázó tényezők egyúttal a képzettségi prémium alakulását is meghatározhatják. Az Egyesült Államokban kialakuló termelékenységi rés az európainál némileg nagyobb béregyenlőtlenséghez kapcsolódik. A vizsgált strukturális jellemzőkön túl jelentősek a különbségek az emberi tőke javadalmazásában. Különösen fontos, hogy az Egyesült Államokban nagyobb a magasan képzett alkalmazottak aránya, akik hatékonyabban is dolgoznak. (Ez utóbbiak valószínüleg összefüggenek az oktatási és migrációs politika különbözőségeivel.)

A teljes tényezőtermelékenység növekedési ütemének egyes fejlett európai országokban megfigyelhető lassulása összefügg a második világháború utáni európai fejlődés sajátosságaival. A jelzett időszak zömében az európai gazdaságok viszonylag sikeres, ám idővel megtorpanó felzárkózást valósítottak meg, amelynek központi eleme az amerikai technológiai haladás utánzása volt. A globális technológiai élmezőnyhöz történő felzárkózás során azonban a jelzett imitatív irányzat csak korlátozott lehetőségeket nyújt. A technológiai élmezőnyben (vagy annak közelében) megkerülhetetlen a szakpolitikák és intézmények újraalakítása az innovációalapú gazdasági modellre: a korábbinál kisebb hangsúllyal az elérhető, élmezőnybeli technológiák és gyakorlat utánzására, s meghatározó súllyal az EU innovációs kapacitásának növelésére.

\section{A pénzügyi és gazdasági válság és következményei}

Az európai gazdaság aktuális kibocsátásának drámai csökkenése a 2008-ban kezdődött pénzügyi és gazdasági válság során több volt mint a potenciális kibocsátástól történő ciklikus eltérés. A potenciális kibocsátás szintje és növekedési üteme egyaránt kedvezőtlenül alakult.

A potenciális növekedést érő tartós hatások valószínűsége a 2008-2009. évi pénzügyi és gazdasági válság után jóval nagyobb, mint a korábbi recessziók esetében. A kockázattal összefüggő magatartás tartós változása a tőkeköltségek növekedéséhez, a tőkeakkumuláció korábbinál mérsékeltebb szintjéhez vezethet. Mindez a fizikai tőkeberuházásokon túl az immateriális beruházások (azon belül a $\mathrm{K}+\mathrm{F}$ ) s a teljes tényezőtermelékenység növekedését is mérsékelheti. A strukturális munkanélküliség egyes tagállamokban tartósan magas szinten maradhat. E tényezők - a termelési függvényre épülő szimulációk szerint - a kezdeti szinthatáson túl közép- és hosszú távon is a potenciális növekedés ütemének csökkenését idézik elő a tagállamokban. 
A pénzügyi és gazdasági válság a különböző EU-tagországokat különböző mértékben érintette. Eltérö ütemü a kilábalás, $s$ az egyes tagállamok növekedési modellje is különböző. Az eltérő egyensúlyi helyzet, az adósságállomány csökkentésének eltérő igénye önmagában lényegesen különböző növekedési lehetőségeket teremtett az egyes tagállamok számára. Mindezekkel kapcsolatban egyes helyeken jelentősen csökkent a beruházási ráta, $s$ tartósan magassá vált a strukturális munkanélküliség, míg másutt kedvezőbbek a feltételek. A külső egyensúlyi problémákkal küzdö, többnyire sérülékeny tagállamok rákényszerültek folyó fizetési mérlegük egyenlegének javítására, kivitelük növelésére s a belső kereslet korlátozására. Mindezek általában együtt jártak a termékegységre jutó munkaköltségek - a versenyképesség visszaszerzéséért megvalósított - csökkentésével.

A potenciális növekedés és az egyes tényezők hozzájárulása tekintetében a legkedvezőtlenebb irányzatok a mennyiségi elemzés ${ }^{13}$ szerint a „mediterrán” és egyes „sérülékeny” új tagállamok esetében mutatkoznak a 2018-ig terjedő középtávú időszakban. A „mediterrán” országcsoportban a felzárkózás a vizsgált időszakban (középtávon) leállt, illetve éveken át divergencia érvényesülhet a fejlett tagállamokhoz képest. A „sérülékeny” új tagállamok átlagában a felzárkózás üteme a válság előtti töredékére csökken. Egyes új tagállamok esetében a felzárkózás a vizsgált években megszünik, illetve távolodás is kialakulhat. Ezekben az országokban már rövid távon is leállhat a reálkonvergencia, sőt azt távolodás válthatja fel. (Ezt neveztük „konvergenciakrízisnek” - Halmai-Vásáry [2012]).

Döntő jelentőségű a szerkezeti alkalmazkodás, az erőforrások szükséges mélyreható reallokációjának lehetősége. A válságot megelőző években a növekedési potenciál „lopakodó” (a viszonylag kedvező aktuális növekedés által elfedett) eróziója, illetve a nagy mérséklődés időszakában az átmenetileg rendkívül mérsékelt tőkeköltségek az EU-tagállamokban a beruházási ráta magas szintjéhez vezettek. A tőkeakkumuláció azonban nem épült a magas tényezőtermelékenység alapján elérhető magas határtermékre. A beruházási boom döntően a külkereskedelmi forgalomba nem kerülő javak és szolgáltatások (mindenekelőtt az ingatlanágazat) területén valósult meg. A gazdaság túlfütöttsége eszközárbuborékok képződéséhez vezetett, $s$ a válság kirobbanásával a recesszió és a kiigazítás elkerülhetetlenné vált. Mindez a leginkább érintett tagállamokban súlyos külső egyensúlyi problémákkal, a folyó fizetési mérleg jelentős hiányával, növekvő sérülékenységgel járt együtt.

Az elkerülhetetlen alkalmazkodás az erőforrások reallokációját követelte és követeli meg a nem exportálható javakat és szolgáltatásokat elóállító szektorból a külkereskedelemhez kötődő ágazatokba. ${ }^{14} \mathrm{Az}$ exportorientált ágazatok (a növekedés „,mozdonyai") ráadásul termelékenyebbek, arányuk növekedése a hatékonyságot is javítja. Az erőforrások gyors reallokációja mérsékelheti a növekedési potenciált érö veszte-

\footnotetext{
${ }^{13}$ E mennyiségi elemzés 27 EU-tagállamra terjedt ki. Horvátország esetében nem álltak rendelkezésre az elemzéshez megfelelő minőségü növekedési számviteli adatok. Az alkalmazott csoportosítást részletesen tárgyalja Halmai [2014] 180-186. o.

${ }^{14}$ Ebben, $\mathrm{s}$ csakis ebben az értelemben merült fel az európai válságkezelés és alkalmazkodás során az újraiparosítás témaköre. Nem pedig tőkepazarló, autark s piacidegen megoldások, régen meghaladott ágazati szerkezet újjáélesztésének igénye húzódott meg ennek hátterében.
} 
séget. A gyors szerkezeti átalakulást előmozdíthatja a globális értékláncokba történő integráció. Az átcsoportosítás zavarai pedig az erőforrások romló kihasználásához, a munkanélküliség növekedéséhez vezethetnek.

\section{Strukturális problémák}

A válság s a kezdődő kilábalás felerősített egyes korábban is létező gyengeségeket, illetve újabb strukturális problémák kialakulásával járt. A következőkben ezeket a tényezőket vesszük sorra.

1. Mérlegkiigazitás (a tőkeáttétel csökkentése). A válság kezdetét követően Európában a magánadósságok csökkentése lassabban valósult meg, mint az Egyesült Államokban. A vállalatok és a háztartások hitelállománya a GDP arányában a válság kitörését követően is emelkedett. Mindebben szerepet játszott a vállalati szektor alacsony jövedelmezősége Európa egyes térségeiben, egyes, föleg dél-európai országok drágább finanszírozási feltételei, banki gyengeségek, a hitelezési veszteség elkerülése érdekében gyenge vállalatok további finanszírozása („zombifikáció”).

2. A költségvetési konszolidáció kényszere. A válságkezeléssel is összefüggésben felhalmozott államadósságok aránya rendkívül nagy az Európai Unió, azon belül az euróövezet tagállamaiban (2017-ben a GDP 83,5, illetve 89,3 százaléka - EC [2017b] 180. o. 42. táblázat). E hatalmas adósságteher ránehezedik a gazdaságokra, fokozatos csökkentése elkerülhetetlen a következő években. A költségvetési konszolidáció döntő részben a kiadások csökkentése révén valósulhat meg. E kiadáscsökkentés azonban egyúttal - rövid és középtávon - a növekedési lehetöségeket is korlátozhatja.

3. A bankok szerepe. A gazdasági növekedés szempontjából központi fontosságú pénzügyi közvetítés Európában a bankokra épül (bár fokozatosan nő a tőkepiacok szerepe). A bankhitelek állománya az euróövezet tagállamainak többségében 2008 után alacsony szinten alakult. E tendenciát jól jellemezheti a vállalati hitelállomány alakulása: az euróövezetben 2015-ben a 2008. évi érték 87,3 százaléka volt. Ugyanez az arány azonban Írországban 31,5, Szlovéniában 48,9, Spanyolországban 58,8, Portugália esetében pedig 69 százalék volt (ECB [2017]). A hitelnövekedés különösen mérsékelt volt Európa déli részén. A hitelkereslet - a gazdasági kilátásokat és a kisebb üzleti bizalmat tükrözve - gyenge. Az államadósság-válság által érintett országokban a hitelezési feltételek szigorúak, és a hitelkínálat korlátozott. A rossz hitelek leírása csökkenti a hitelállományt. Az Európai Központi Bank szerint a monetáris transzmissziós mechanizmus javulása ellenére a monetáris politika nem minden európai országban volt képes növelni a likviditást. A bankok megterhelik a növekedést, amikor gyenge mérleget felmutató, drága finanszírozást nyújtó, fizetésképtelen piaci szereplőket is hiteleznek. A válság kezdetétől az európai bankrendszer meggyengült, törékennyé vált.

4. Pénzügyi fragmentáció. A tagállamok pénzpiacainak müködésében és teljesítményében olyan eltérések találhatók, amelyeknek oka a tőke és/vagy a pénzügyi szolgáltatások határokon át történő szabad mozgásának akadályozása (Al-Eyd-Berkmen [2013]). Az euró bevezetése óta az euróövezeti bankszektorban erőteljes integráció valósult meg, főleg a vállalati hiteleket és a tökepiacokat illetően. A pénzügyi válság, 
még inkább az államadósság-válság megfordította ezt a folyamatot: mérséklődött a határokon átnyúló bankközi hitelezés. A bankok finanszírozási költségei (a vállalati szegmensben) és a hitelbiztosítás (CDS) díjai az érintett ország helyzete - annak államkötvényhozamai - szerint alakultak. A pénzügyi fragmentáció különösen hátrányos hatásokkal járt a sebezhető tagállamokban található bankok számára. A kisés közepes méretủ vállalatokat általában erösebben érintik a visszaesések, illetve az aszimmetrikus sokkok, mint a diverzifikáltabb nagyvállalatokat. Minthogy a kis- és középvállalatok lényegesek a gazdasági növekedés és munkahelyteremtés tekintetében, a pénzügyi fragmentáció fékezheti a helyreállást a sérülékeny tagállamokban, $\mathrm{s}$ felerősítheti a ciklikus divergenciát az euróövezetben.

5. Reál-, illetve nominális merevségek, súrlódások a munka-és termékpiacokon. A munkapiaci merevségek a válságot követően hátráltatják a munkaerő reallokációját, növelik a strukturális munkanélküliséget (non-accelerating wage rate of unemployment, NAWRU), s hozzájárulnak a foglalkoztatási ráta csökkenéséhez. A magas munkanélküliségi szinteket nagyrészt középtávú ciklusok vezérlik, amelyek hosszabb ideig fennmaradhatnak. A reálalkalmazkodás merevségei (az ágazati reallokáció súrlódásai, a rezervációs bérek lassú alkalmazkodása, a képzettség rossz illeszkedése) lassítják a munka elkerülhetetlen reallokációját az érintett ágazatokból (például az építőiparból). Folyamatos reformok hiányában az euróövezeti kockázatok a válság előtti időszakénál jóval magasabb munkanélküliségi rátákhoz vezethetnek a 2020-as évek elején (Orlandi [2012]).

6. Az árak hibás összehangolása (misalignment), tökéletlen alkalmazkodása és a tőke hibás allokációja az euróövezetben. Az ingatlanszektor túlfütöttsége torzította az árakat és a béreket, egyidejüleg a tőke hibás allokációjához vezetett az EU számos tagállamában. E túlfütöttség, ingatlanpiaci buborék képződése miatt megnövekedett az építőipar részaránya a recesszió előtti években. A kibocsátás a potenciális szint fölé került; az alkalmazkodás elkerülhetetlen volt. Egyidejűleg a feldolgozóipar aránya szignifikáns módon csökkent Dél-Európában és Franciaországban. (A kontinens északi felén ez az arány viszonylag stabil maradt.) Az euróövezetben e folyamathoz a relatív árak lényeges torzulása társult. Az euróövezet déli tagállamaiban az euró reálértelemben túlértékeltté vált, ${ }^{15}$ a legtöbb északi tagállamban viszont alulértékelt lett. Minthogy az eurónak nincs tagállamonként önálló árfolyama, csak az euróövezeten belüli alkalmazkodás igazíthatja ki ezeket az eltéréseket (Darvas és szerzőtársai [2013]).

7. A tőkeakkumuláció lassulása. A válság időszaka a tőkefelhalmozás drámai csökkenésével járt (12. ábra). A kockázati felárak emelkedése, a bankok óvatosabb magatartása és a beruházási túlfütöttség utáni korrekció a beruházási ráta visszaeséséhez vezetett. A fizikai töke felhalmozásának szükségszerü visszaesése a mérlegkiigazítás folyamatával egyidejüleg, a tőkeallokáció rendszerének korábban már bemutatott torzulásaival együtt érvényesül. Mindez a tőke optimálisnál rosszabb allokációjával jár a restrukturálódás szakaszában, $s$ ránehezedik a potenciális növekedésre középés hosszú távon is (Furceri-Mourougane [2009]).

\footnotetext{
${ }^{15}$ Hasonló irányzatok mutatkoztak a balti tagállamokban is.
} 
12. ábra

Összes beruházás, fejlett gazdaságok $(2008=100)$

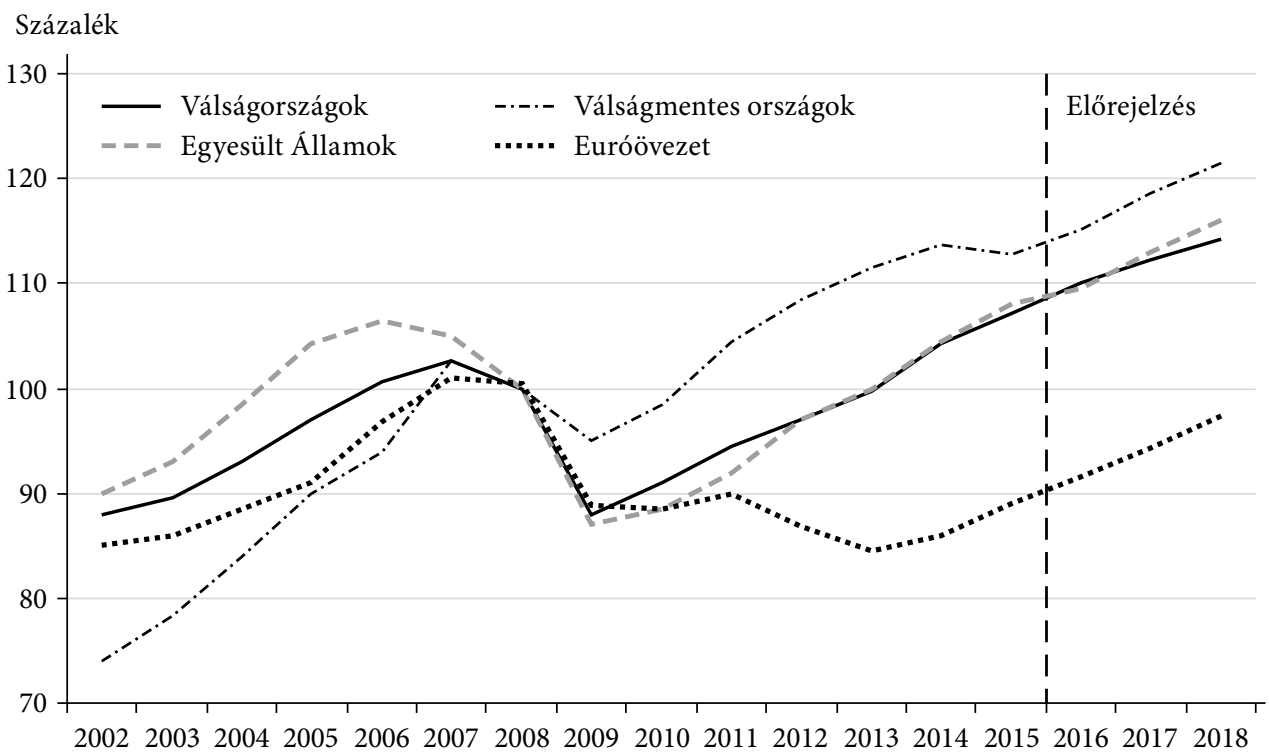

Megjegyzés: válságországok (Egyesült Királyság, Egyesült Államok, Japán, Svájc, Svédország) súlyozott átlaga, válságmentes országok (Ausztrália, Kanada, Dél-Korea, Norvégia, Új-Zéland) súlyozott átlaga.

Forrás: EC [2017a] 11. o.

A fizikai beruházások hatást gyakorolnak a hosszú távú technológiai haladásra is: például visszaesésük fékezheti az immateriális beruházásokat. Ez pedig negatív hatást fejt ki a hosszú távú innovációra, a teljes tényezőtermelékenység alakulására, az új, élvonalbeli technológiák fejlődésére és elterjedésére (Barley [2007], Aghion és szerzőtársai [2008]). Ám a válság tisztító és szerkezeti átalakulást kikényszerítő hatásai a teljes tényezőtermelékenység pozitív változásait is előmozdíthatják (Caballero-Hammour [1994]).

8. Idösödö népesség és a munka hozzájárulása a potenciális növekedéshez. A munka hozzájárulása a válság mélypontját követően szerény mértékben ismét nőhet. A kilábalás időszakában pozitív hozzájárulás várható a strukturális munkanélküliség csökkenéséből, illetve a részvételi ráták szerény növekedéséből. Ám a várható demográfiai hatások miatt a jelenlegi évtized végére a munkaképes korú népesség hozzájárulása, a munkakínálat növekedése egyre inkább kifullad a potenciális növekedés hajtóerői között.

A rövid és középtávú kihívások hátrányos kölcsönhatásai, továbbá a hosszú távú kedvezőtlen irányzatok tartósan ránehezednek az EU-tagállamok gazdasági teljesítményére. Ha a mérlegkiigazítás szükségessége, a strukturális merevségek és a bankszektor gyengeségei fennmaradnak, az erőforrások reallokációja lassú maradhat. A mérsékelt növekedési potenciál korlátozza az állam- és a magánadósságok leépítését, egyben a pénzügyi közvetítés lehetőségeit. Az elhúzódó növekedési válság és depresszió megnehezítik a közpénzügyek megszilárdítását s a versenyképesség 
visszaszerzését a mediterrán országokban. Mindezek a tényezők csökkentik az európai országok tőkevonzó képességét. A jelzett feltételek a növekedés megtorpanásával, egyes tagállamok tartós stagnálásával fenyegetnek.

\section{A növekedési modell kifulladása}

Az európai növekedési modell eróziója, majd válsága fékezte a termelékenység javulását, a potenciális növekedést, továbbá a kevésbé fejlett országok felzárkózását (a modell 3., 4. és 5. fő jellemzője). A növekedési potenciál sokáig látens és fokozatos leépülése a pénzügyi és gazdasági válság kitörését követően nyílt növekedési válsággá vált. A felzárkózási növekedés a válság kitörését követően a kibővült Európai Unióban is megszűnt, jelezve az európai növekedési modell válságát.

Az európai konvergenciamechanizmus a lappangó, majd a nyílt növekedési válság időszakától megrendült. Annak következtében az integráció egységes mechanizmusa müködésképtelenné válhat. A konvergencia ismételt megindulása az európai megújulás, az európai reformok alapvető kihívása s egyben feltétele.

A kedvezőtlen beruházási környezetben gyorsul a tőkekiáramlás, és jelentősen növekszik az áru- és szolgáltatásimport aránya. A nagyfokú külső nyitottság (a modell 1. jellemzője) változatlanul érvényesül, ám egyes tagállamok globális versenyképessége kedvezőtlenül alakult a legutóbbi másfél-két évtizedben. A globális tőkemozgások rendszerében Európa egyre inkább tőkeexportőr, ami - kedvező gazdasági hatásai mellett - korlátozza az európai foglalkoztatást és a növekedési potenciált (a modell 2. jellemzője). ${ }^{16}$ Mindezek a problémák, továbbá a közpénzügyek egyensúlyának zavarai, a fenntartható közpénzügyek igénye egyre inkább összeütközésbe kerülnek a társadalmi és környezeti felelösség, a szolidaritás európai modelljének sajátosságaival (a modell 6. jellemzője). Végül a növekedési modell kihívásainak európai kezelését megnehezíti az európai kormányzás mindeddig elégtelen szintje (a modell 7. jellemzője). Mindezek következtében az integráció első évtizedeiben látványos sikereket hozó európai növekedési modell - hosszú, látens erózió után - az ezredforduló utáni első évtizedben kifulladt.

\section{Korszakos stagnálás?}

Ezen a ponton eljutottunk a korszakos stagnálás (secular stagnation) hipotéziséhez. E hipotézist elöször Alvin Hansen fejtette ki az Amerikai Közgazdasági Társaság 1938. decemberi, Detroitban tartott ülésén (Hansen [1939]). A korszakos

\footnotetext{
${ }^{16}$ Az EU27 külföldi (azaz: a világ EU-n kívüli részéhez kapcsolódó) közvetlen befektetéseinek (FDI) egyenlege - a válság mélypontját kivéve - a legutóbbi években az Eurostat adatai szerint évi 120-180 milliárd euró körül alakult, azaz ennyivel több működőtőke áramlott ki az EU27-ből, mint amennyi beérkezett. Ugyanakkor az EU-n belül nagyon eltérő a tőkeintenzitás és a tőke határterméke. Ösztönző beruházási klíma esetén e nettó tőkekiáramlás - logikus feltételezéssel élve - kevesebb, az EU-n belüli beruházás és potenciális növekedés pedig több lenne. (A beruházási ráta az Egyesült Államokban 1992 óta minden évben magasabb, mint az EU15 országaiban.)
} 
stagnálás koncepcióját a közelmúltban Larry Summers helyezte ismét a viták középpontjába [Summers [2014]).

A korszakos stagnálás magyarázatára kétféle megközelítés lehetséges. Az első (ilyen például Summersé) az aggregált kereslet hiányát, az állandósuló likviditási csapdát tekinti meghatározónak. Ebben az esetben a gazdaság nulla közeli kamatszint mellett sem juthat vissza a korábbi potenciális növekedési pályára.

A másik magyarázat a strukturális változásokon alapuló kínálati oldali tényezőket tekinti meghatározónak. A több éve tartó lassulás és az alacsonyabb kamatok a potenciális növekedés erózióját tükrözik. Ezért ez utóbbi megközelítésben nem sok értelme van a keresletélénkítő gazdaságpolitikának: az alacsony potenciális növekedési ütemet tartósan úgysem lehet meghaladni. A strukturális változásokon alapuló kínálati oldali tényezők körébe elsősorban a technológiai fejlődés, illetve a termelékenység növekedésének kilátásai, a demográfiai folyamatok, az idősödés tartoznak. (Ugyanakkor hasonló hatásokkal járhat nagyarányú államadósság kialakulása vagy az egyenlötlenségek növekedése.)

Mindezek nyomán a korszakos stagnálás elmélete szerint az állandósuló depresszió lehet a gazdaság „új normális” (new normal) állapota. Ennek lehetőségét szem előtt tartva alapvető kérdés: hogyan alakul a vezető gazdaságban a technológiai haladás?

Robert J. Gordon, a Northwestern Egyetem professzora szkeptikus megközelítést képvisel (Gordon [2014]). Az elmúlt évtizedek lassulását elsősorban a munkatermelékenység dinamikájának tartós visszaesésével magyarázza. Álláspontja szerint a mostani lassulás természetes korrekció lehet az elmúlt kétszáz év gyorsabb növekedése után. Az elmúlt két évszázad három nagy ipari forradalma közül az első kettő során olyan találmányok, felfedezések láttak napvilágot, amelyek sokkal jobban gyorsították a gazdasági növekedést, mint a harmadik, az 1980-as években kezdődő, napjainkban is zajló, a számítástechnikára, digitalizációra épülő ipari forradalom. A korábbi időszakok technológiai áttöréseinek eredményei „alacsonyan lógó gyümölcsök" voltak: viszonylag könnyen és gyorsan nagy változást, jelentős hatékonyságnövekedést tudtak elérni. A jelenlegi technológiai haladásnak viszont a korábbiaknál jóval kisebb a növekedésre gyakorolt pozitív hatása.

Más amerikai közgazdászok (Byrne és szerzőtársai [2013], Frey-Osborne [2013]) azonban az infokommunikáció, a robotika, a nanotechnológia lehetőségei alapján a termelékenység növekedésének esélyét emelik ki. Mokyr [2014] szerint a teljes tényezőtermelékenység növekedésének akár szignifikáns gyorsulása is elképzelhető a közeljövőben.

A potenciális növekedés a vezető gazdaságban elsősorban a demográfiai és a szélesebb értelemben vett technológiai fejlödéstől függ. A követő (európai) gazdaságokban a teljes tényezőtermelékenység hosszú távú növekedése a TFP amerikai dinamikáján és az Egyesült Államokhoz képest fennálló termelékenységi rés csökkentésének ütemén alapul. A felzárkózási növekedés tere az elmúlt két évtized kedvezőtlen folyamatai után Európában kibővült. Az egy munkaórára jutó reál-GDP (Németország, Franciaország és Olaszország átlagában) 1995-ben az Egyesült Államok azonos adatának 88,7, 2007ben 79,9, 2013-ban pedig már csak 76,0 százaléka volt (Crafts [2015]). 
A fokozatos feltételes konvergencia az érintett európai országok számára a megfelelő intézmények és makrogazdasági politika megléte esetén lehetséges. Mindez a kínálati oldali reformok, a piactámogató, növekedésbarát politika jelentőségét és lehetőségeit emeli ki. A korszakos stagnálás tehát valóságos veszély, ám nem elkerülhetetlen szükségszerüség.

\section{Növekedési fordulat - az európai növekedési modell megújítása}

Az európai növekedési modell megújítása növekedési fordulatot, új középtávú növekedési narratíva felvázolását követeli meg. Az analitikai és a stratégiai gondolkodást egyaránt hasznosan foglalja keretbe, ha választ keresünk arra a kérdésre, hogyan lehet helyreállítani Európa gazdasági prosperitásának háromszögét: a gazdasági növekedést, a stabilitást és a méltányosságot a nyitott és demokratikus társadalmakban (13. ábra). ${ }^{17}$

13. ábra

Az európai prosperitás háromszöge
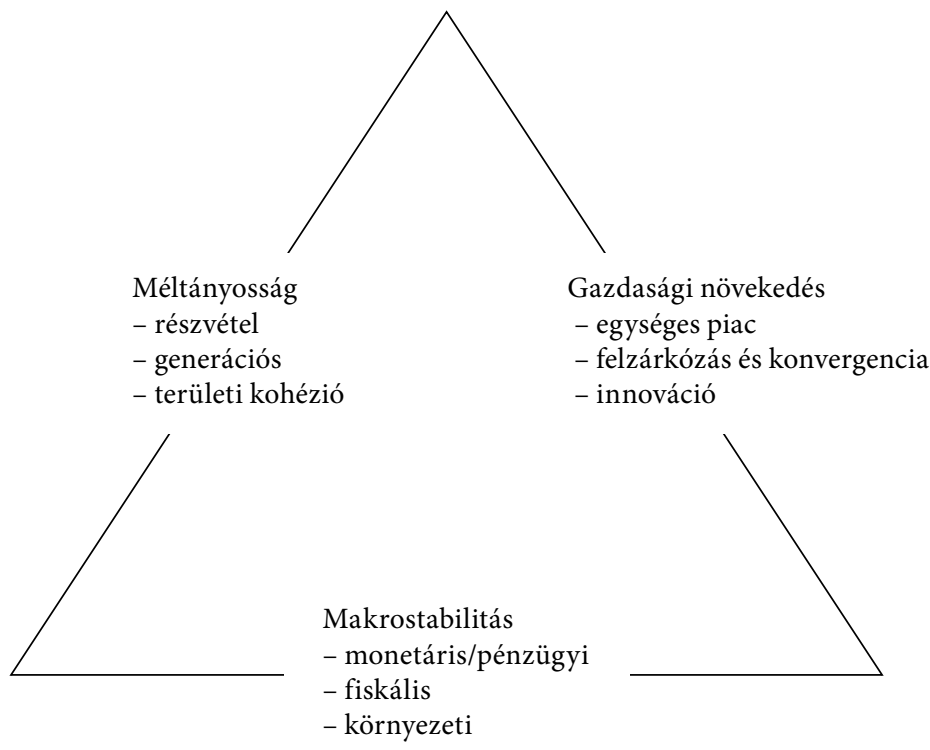

Forrás: Pichelmann [2013] 1. ábra.

Az európai növekedési potenciál és a növekedési modell újjászületésének egyedüli lehetősége az európai gazdaság és társadalom müködési módjának mélyreható, a potenciális növekedést támogató strukturális reformok révén történö megújitása.

Nagy jelentőségű az erőforrások rugalmas reallokációja, az azt előmozdító strukturális reformok megindítása, mert ezek nélkülözhetetlenek az új technológiák

\footnotetext{
${ }^{17}$ E szempontokat is elemzi Csaba [2014], [2018].
} 
széles körű elterjedéséhez. Alapvetők a reallokáció munkapiaci kihívásai, továbbá a tanulásra ösztönzés, illetve a bérkülönbségekkel kapcsolatos megfontolások. A jelenlegi és az elöre látható technológiák fontos jellemzői: a létrehozás magas állandó és az alkalmazás alacsony marginális költségei a jövedelemingadozás növekedését, illetve az elosztás további torzulását okozhatják. Bartelsman [2013] szerint a közszolgáltatások (például egészségbiztosítás, oktatás) reformjai nemcsak közvetlen módon növelhetik az aggregált termelékenységet, hanem felszívhatják a más ágazatokból elbocsátott dolgozókat.

A növekedési fordulatot középpontba állító stratégia döntő mozzanata a piac működését javító, a növekedési potenciált erősítő strukturális reformok révén a termelékenység gyorsabb növekedésének elömozdítása. Az erőforrások hatékonyabb felhasználása mellett alapvető cél a foglalkoztatási ráta fenntartható növelése is.

A növekedési potenciált támogató strukturális reformok alapvető eleme a belső piac jobb müködésének megteremtése és az üzleti környezet javitása lehet. Mindezek eredményeként enyhülhetnek a piaci torzulások, javulhatnak a beruházások, az innováció lehetőségei, erősödhet az EU versenyképessége. Mindehhez mélyreható reformok szükségesek a termék- és a szolgáltatáspiacok, illetve az erőforráspiacok, elsősorban a munkaerö- és a pénzpiac területén. Az előbbiekkel szorosan összefüggnek, s azokhoz hasonló jelentőségủek a tudást és az innovációt előmozdító reformok.

A termék- és szolgáltatáspiaci reformok meghatározó elemei a belső piac teljes megnyitása (liberalizáció, dereguláció), a piacra lépés megkönnyítése, az adminisztratív terhek csökkentése, a verseny intenzitásának növelése, egyidejüleg az árköltség-rés csökkentése. A pénz- és tőkepiaci reformok rugalmasabb finanszírozási feltételek (közöttük a tőkepiaci unió), mindazok révén pedig alacsonyabb tranzakciós költségek, jobb kockázatmegosztás, hatékonyabb erőforrás-allokáció, a kockázati felárak mérséklődésének lehetőségét teremtik meg. A munkapiaci reformok a munkapiac bővítését, az emberi erőforrások és az üres álláshelyek illeszkedésének javítását, a munkapiac adaptációs képességének erősítését célozzák. Mindennek révén javulhat a munka hasznosítása, a munkakínálat növekedhet, a strukturális munkanélküliség pedig csökkenhet.

A tudást és innovációt elömozdító reformok között alapvető a tudásháromszög fejlesztése: a tudás behatolása (élethosszig tartó tanulás), az új tudásnak a meglévőhöz történő hozzáadása ( $\mathrm{K}+\mathrm{F}$, oktatás) és a mindennapi életben történő alkalmazása (technológiai, termék- és folyamatinnováció). Mindezek előfeltétele - egyebek mellett - az oktatási és K + F-beruházások arányának a növelése. Jones [2002] szerint 1950 és 1993 között az Egyesült Államok növekedésének egyharmada az emberi tőke akkumulációjából származott. Az oktatási reformok hatalmas gazdasági potenciálját hangsúlyozza Hanushek-Woessmann [2012]: valamennyi EU-tagállam oktatásának a legmagasabb szintet teljesítő Finnország minőségi színvonalára történő emelkedése mintegy 20 százalékkal növelhetné az EU GDP-jét. Az európai felsőoktatási és kutatási térség jelentős, a teljes tényezőtermelékenység növekedését előmozdító tovagyürüzések feltételeit teremti meg.

A kinálati oldali (strukturális) reformok hatásvizsgálata (a reformok révén elérhető potenciális haszon lehetséges nagyságának bemutatása) során az első lépés az „élen 
járó" indikátorok mint viszonyítási alap (benchmark) meghatározása (például a legjobb három EU-tagállam átlaga alapján). E vizsgálatok a teljesítményrések csökkenésének hatásait mint reformpotenciált szimulálják.

Barnes és szerzőtársai [2011] modellszámításai szerint, ha az egyes strukturális indikátorok tekintetében átlagos EU-tagállamok elérnék az OECD átlagos szintjét, tíz év alatt a GDP-jük mintegy 10 százalékát képviselő növekedési többletre tehetnének szert. Egyes országok esetében azonban a potenciális GDP-többlet ennél jóval nagyobb (4. táblázat).

4. táblázat

Kínálatoldali reformok hatása az egy főre jutó GDP-re (százalék)

\begin{tabular}{lc}
\hline Ország & Hatás \\
\hline Egyesült Királyság, Hollandia & $3,2-5,7$ \\
Ausztria, Dánia, Svédország & $10,7-13,0$ \\
Finnország, Írország, Olaszország, Németország, Spanyolország & $16,0-17,4$ \\
Belgium, Franciaország & $19,7-21,2$ \\
Görögország, Portugália & $39,6-43,9$ \\
Svájc & 13,2 \\
Egyesült Államok & 4,2 \\
\hline
\end{tabular}

Forrás: Barnes és szerzőtársai [2011].

A kölcsönhatások egyik figyelemre méltó területe a termék- és munkapiaci reformok együttes hatása. Ezek fö tényezői a bérek alakulása, az erősebb versenyre kényszerítő hatás és a termelékenység növekedése. A termékpiaci reformok három fö mechanizmus révén gyakorolnak hatást a munkaerőpiacra. Egyrészt a termékpiaci verseny erősödése növeli a kibocsátást és a munkaerő-keresletet, a munkakereslet bérek iránti érzékenysége pedig erősödik. Másrészt az intenzívebb termékpiaci verseny mérsékeli a gazdasági járadékot. Harmadrészt, élesebb versenyben a vállalatok alacsonyabb költséggel termelnek, hatékonyabban müködnek, ami az erőforrások jobb kihasználásához és a teljes tényezőtermelékenység növekedéséhez vezet.

Az egyes reformterületek közötti kölcsönhatások lényeges területe a termékpiaci dereguláció és integráció, valamint a tudásba történő befektetés együttes hatása.

A szabályozási reformok alapvető célja a kedvezőbb, a beruházásokat ösztönzö üzleti környezet elömozdítása. Az európai gazdaság még mindig erősebben szabályozott, mint az amerikai. Az amerikai hatékonyság eléréséhez a deregulációt további strukturális reformoknak kell követniük.

A K $+\mathrm{F}$ területén nem egyszerüen a közkiadások növelése, hanem a kutatási kiadások endogén növekedését elősegítő feltételek kialakítása a strukturális reformok célja. Annak alapvető tényezői a termékpiacok erösebb integrációja, a hatékonyabb oktatás és a pénzpiacok hatékonyabb müködése.

A strukturális reformok átfogó és összehangolt alkalmazása jelentös szinergikus hatásokat eredményezhet. A termék- és tőkepiaci reformok révén is elömozdított 
új üzleti lehetőségek csak akkor használhatók ki, ha megfelelően képzett munkaerőt lehet megfelelő feltételek között foglalkoztatni. A versenyképességet fokozottan kikényszerítő, vállalkozásbarát üzleti környezet előmozdítja a beruházásokat és az innovációt. A termék-, a tőke- és a munkaerőpiacok strukturális reformjai erősítik az üzleti környezetet, javítják a piac müködését. E reformoknak köszönhetően az erőforrások az alacsonyabb termelékenységü területekről a magasabb termelékenységüekhez áramlanak.

A strukturális reformokkal összefüggésben a keresleti tovagyürüzések, a versenyképességi hatások, a nemzetközi pénzügyi áramlások és a tudás-tovagyürüzés érdemelnek külön kiemelést.

Figyelemre méltóak a pozitív szinergiát előmozdító reformcsomagok alkalmazásával összefüggő tapasztalatok. A strukturális reformokat nem egyetlen uniformizált modell szerint lehet megvalósítani. Európában két különböző (az angolszász, illetve a skandináv) modell egyaránt a növekedés és a munkahelyteremtés jó gyakorlati példájának tekinthetö. Az érintett országok alapvető közös jellemzője, hogy még a 20. század utolsó évtizedében viszonylag átfogó és integrált, pozitív szinergiát eredményező gazdasági reformokat terveztek és indítottak el a piac jobb müködése érdekében. E változások vonzó vállalkozási környezetet, gazdasági dinamizmust eredményeztek. ${ }^{18}$

Paradox módon a strukturális reformok a legszerényebb indikátorértékekkel rendelkező országokban lehet(né)nek a legeredményesebbek. (Ez a reformpotenciál paradoxona.) Âm a megfelelő társadalmi-gazdasági és intézményi feltételek hiányában a strukturális reformok sem valósíthatók meg sikeresen. A strukturális indikátorok alacsony értékei esetén a reformok csak akkor lehetnek sikeresek, ha a fennálló rendszer mélyreható átalakítására, a társadalmi-gazdasági fejlődés új útjának megalapozásaként (path creation) alkalmazzák őket.

\section{Néhány következtetés}

Végiggondolva az elemzés fö eredményeit, megfogalmazható néhány tanulság is.

- Az európai integráció növekedési szinergiát eredményez. Az integráció eredménye növekedési többlet; a dezintegráció szükségszerüen növekedési veszteséghez vezet.

- Az európai növekedési potenciál erősítésének döntő tényezője, egyben az európai versenyképesség növelésének előfeltétele a világ vezető gazdaságához képest fennálló termelékenységi rés csökkentése.

- Az európai integráció müködésének feltétele a konvergenciamechanizmus érvényesülése. Annak hiányában a rendszer stabilitása sérülne, $s$ dezintegrációs irányzatok erösödhetnének fel.

- Átfogó kínálati oldali (strukturális) reformok átütő erejű megvalósítása adhat csak esélyt európai növekedési fordulatra. E reformok az európai növekedési modell

${ }^{18}$ A társadalmi és a környezeti összefüggések figyelembevételével a skandináv modell teljesítménye kedvezőbb. Ugyanakkor a brexit felmérhetetlen kárt okoz az európai reformpolitikának: a strukturális reformokban élen járó, egyes mutatókban viszonyítási alapnak minősülő tagállam készül elhagyni az átfogó reformok előtt álló Európai Uniót. 
megújítását, a globalizáció kihívásaihoz történő fokozott alkalmazkodás lehetőségét teremthetik meg. Reformok hiányában pedig megállíthatatlan lehet a leszakadás a világgazdaság legdinamikusabb szereplőitől.

- A politikai versengés viszonyai között felerösödött az érzelmekre, a médiamanipulációkra alapozott „tényeken túli” politikai befolyásolás igénye. [Felmerült, hogy immár maga a korszak is a „tényeken túli társadalom” (post factual society) fogalmával írható le.] Az aszimmetrikus információkon, a választók demagóg és manipulatív befolyásolásán nyugvó populizmus térhódítása nagy kihívás a demokrácia, egyúttal az európai nemzeteket egyesítő európai integráció számára is. A populizmusnak súlyos ára van..$^{19} \mathrm{~A}$ tudomány felelőssége, hogy a társadalom számára a társadalmi és gazdasági alapkérdések tekintetében pontos és kiegyensúlyozott információkat nyújtson. Valamennyi EU-tagállamban alapvető jelentőségü, hogy a társadalom helytálló információkat kapjon az integráció tényleges és potenciális hatásairól.

\section{Hivatkozások}

Abadie, A.-Diamond, A.-Hainmueller, J. [2010]: Synthetic Control Methods for Comparative Case Studies: Estimating the Effect of California's Tobacco Control Program. Journal of American Statistical Association, Vol. 105. No. 490.493-505. o. https://doi.org/10.1198/ jasa.2009.ap08746.

Abadie, A.-Diamond, A.-Hainmueller, J. [2012]: Comparative Politics and the Synthetic Control Method. Kézirat, Harvard University.

Aghion, P.-Askenazy, P.-Berman, N.-Cetteand, G.-Eymard, L. [2008]: Credit constraints and the cyclicality of R\&D investment. Evidence from France. PSE Working Paper, No. 198. https://doi.org/10.2139/ssrn.1680324.

Aghion, P.-HowitT, P. [2005a]: Appropriate growth policies. A unifying framework. Journal of the European Economic Association, Vol. 3. No. 2-3. 269-314. o. https://doi.org/10.1162/ jeea.2006.4.2-3.269.

Aghion, P.-HowitT, P. [2005b]: Growth with quality-improving innovations: An integrated framework. Megjelent: Aghion, P.-Durlauf, S. (szerk.): Handbook of Economic Growth. Vol. 1A. Elsevier B. V., 67-110. o. https://doi.org/10.1016/S1574-0684(05)01002-6.

Aghion, P.-Howitt, P. [2006]: Appropriate Growth Policy: A Unifying Framework. Joseph Schumpeter Lecture. Journal of the European Economic Association, Vol. 4. No. 2-3. 269314. o. https://doi.org/10.1162/jeea.2006.4.2-3.269.

Al-Eyd, A.-Berkmen, P. [2013]: Fragmentation and Monetary Policy in the Euro Area. IMF Working Paper, Vol. 13. No. 208. https://doi.org/10.5089/9781484328750.001.

BADINGER, H. [2005]: Growth Effects of Economic Integration: Evidence from the EU Member States. Review of World Economics, Vol. 141. No. 1. 50-78. o. https://doi.org/10.1007/ s10290-005-0015-y.

BADINGER, H. [2008]: Technology- and investment-led growth effects of economic integration: Evidence from the EU member states. Applied Economics Letters, Vol. 15. No. 7. 557-561. o. https://doi.org/10.1080/13504850600711669.

\footnotetext{
${ }^{19}$ A brit választópolgárok jelenleg szembesülnek azzal, hogy elemi információk hiányában szavaztak a brexitről.
} 
BALDWIn, R.-Wyplosz, C. [2012]: Economics of the European Integration. McGraw-Hill, Berkshire.

BArlevy, G. [2007]: On the Cyclicality of Research and Development. American Economic Review, Vol. 97. No. 4. 1131-1164. o. https://doi.org/10.1257/aer.97.4.1131.

Barnes, S.-Bouis, R.-Briard, P.-Dougherty, S.-Eris, M. [2011]: The GDP Impact of Reform: A Simple Simulation Framework. OECD Economics Department Working Paper, No. 834. https://doi.org/10.1787/5kgk9qjnhkmt-en.

Barro, R. J.-Sala-I-Martin, X. [2003]: Economic Growth. Második kiadás, MIT Press, Cambridge, MA.

Bartelsman, E. J. [2013]: ICT, Reallocation and Productivity. European Economy, Economic Papers, No. 486. Brüsszel, http://ec.europa.eu/economy_finance/publications/economic_ paper/2013/pdf/ecp486_en.pdf.

Bayoumi, T.-Eichengreen, B. [1995]: Is Regionalism Simply a Diversion? Evidence from the Evolution of the EC and EFT. IMF Working Paper, Vol. 95. No. 109. https://doi. org/10.5089/9781451853155.001.

BEREND, T. Iván [2008]: Európa gazdasága a 20. században. História Könyvtár. MTA Történettudományi Intézete, Budapest.

Berend T. Iván [2016]: The History of European Integration. A new perspective. Routledge, London - New York.

Boltho, A.-Eichengreen, B. [2008]: The Economic Impact of European Integration. CEPR Discussion Paper, No. 6820.

Byrne, D.-Oliner, S.-Sichel, D. E. [2013]: Is the Information Technology Revolution Over? International Productivity Monitor, Vol. 25. 20-36. o. https://doi.org/10.2139/ ssrn.2240961.

Caballero, R. J.-Hammour, M. L. [1994]: The cleansing effects of recessions. American Economic Review, Vol. 84. No. 5. 1350-1368. o. http://www.jstor.org/stable/i337080.

Caballero, R.-Cowan, K.-Engel, E.-Micco, A. [2004]: Effective Labor Regulation and Microeconomic Flexibility. NBER Working Paper, No. 10744. https://doi.org/10.3386/ w10744.

Campos, N. F.-Coricelli, F.-Moretti, L. [2014]: Economic Growth and Political Integration: Estimating the Benefits from Membership in the European Union. Using the Synthetic Counterfactuals Method. IZA Discussion Paper, No. 8162. Forschungsinstitut zur Zukunft der Arbeit. Institute for the Study of Labor, Bonn, http://ftp.iza.org/ dp8162.pdf.

Campos, N.-CoRicelli, F. [2015]: Some unpleasant Brexit econometrics. VOX CEPR's Policy Portal, december 11. http://voxeu.org/article/some-unpleasant-brexiteconometrics.

Cecchini, P.-Jacquemin, A.-Robinson, J.-Catinat, M. [1988]: The European challenge 1992: The benefits of a single market. Wildwood House, Aldershot.

Coe, D. T.-Helpman, E. [1995]: International R \& D Spillovers. European Economic Review, Vol. 39. No. 5. 859-887. o. https://doi.org/10.1016/0014-2921(94)00100-E.

Crafts, N. [2012]: Western Europe's Growth Prospects. A Historical Perspective. University of Warwick Department of Economics, Coventry, CAGE Online Working Paper Series, http://wrap.warwick.ac.uk/57767/1/WRAP_71.2012_crafts.pdf.

Crafts, N. [2015]: Is Secular Stagnation the Future for Europe? The University of Warwick, Centre for Competitive Advantage in the Global Economy, Department of Economics, Working Paper Series, No. 225. 
Crafts, N.-Toniolo, G. [2008]: European Economic Growth, 1950-2005. An Overview. CEPR Discussion Paper, No. 6863.

Crespo-Cuaresma, J.-Dimitz, M. A.-Ritzberger-Grünwald, D. [2007]: Growth effects of European integration: Implications for EU enlargement. Megjelent: Paganetto, L. (szerk.): The Political Economy of the European Constitution. Ashgate Publishing, Farnham, UK. CsAba LÁszló [2014]: Európai közgazdaságtan. Akadémiai Kiadó, Budapest.

Csaba LÁszló [2018]: Válság, gazdaság, világ. Adalék Közép-Európa három évtizedes gazdaságtörténetéhez (1988-2018). Éghajlat Kiadó, Budapest.

Darvas Zsolt-Pisani-Ferry, J.-Wolff, G. [2013]: Europe's Growth Problem (and what to do about it). Bruegel Policy Brief, No. 3. április, http://bruegel.org/wp-content/uploads/ imported/publications/pb_2013_03_.pdf.

Deardorff, A.-Stern, R. [2002]: EU Expansion and EU Growth. Ford School of Public Policy, Working Paper, No. 487. http://fordschool.umich.edu/rsie/workingpapers/ Papers476-500/r487.pdf.

EC [2017a]: Economic Forecasting. Spring. European Commission DG ECFIN, Brüsszel, https://ec.europa.eu/info/sites/info/files/ip048_en_4.pdf.

EC [2017b]: Economic Forecasting. Autumn. European Commission DG ECFIN, Brüsszel, https://ec.europa.eu/info/sites/info/files/economy-finance/ip063_en.pdf.

ECB [2017]: Euro Area Statistics. European Central Bank, https://www.euro-area-statistics.org.

Eichengreen, B. [2007]: The European Economy since 1945. Coordinated Capitalism and Beyond. Princeton University Press, Princeton, N. J.

Fei, J. C. H.-Ranis, G. [1997]: Growth and Development From an Evolutionary Perspective. Basil Blackwell, Oxford.

Frey, C. B.-Osborne, M. A. [2013]: The Future of Employment: How Susceptible are Jobs to Computerisation? Kézirat, Oxford Martin School.

Friedman, B. M. [2005]: The Moral Consequences of Economic Growth. Vintage Books, New York.

Friedmann, B. M. [2010]: Jólét és erkölcsösség. A gazdasági növekedés és a demokratikus értékek kapcsolatáról - történeti összefüggésben. Napvilág Kiadó, Budapest.

Furceri, D.-Mourougane, A. [2009]: The effect of financial crises on potential output: New empirical evidence from OECD countries. OECD Economic Department Working Paper, No. 699. https://doi.org/10.1787/224126122024.

GILL, I. S.-RAISER, M. [2011]: Golden growth: Restoring the lustre of the European economic model. World Bank, Washington, https://doi.org/10.1596/978-0-8213-8965-2.

Goldin, C. [1995]: Cliometrics and the Nobel. Journal of Economic Perspectives, Vol. 9. No. 2. 191-208. o. https://doi.org/10.1257/jep.9.2.191.

Gordon, R. J. [2014]: The Demise of U. S. Economic Growth: Restatement, Rebuttal, and Reflections. NBER Working Paper, No. 19895. https://doi.org/10.3386/w19895.

Gourinchas, P.-O.-Jeanne, O. [2007]: Capital Flows to Developing Countries: The Allocation Puzzle. NBER Working Paper, No. 13602. https://doi.org/10.3386/w13602.

Grossman, G.-Helpman, E. [1994a]: Endogenous Innovation in the Theory of Growth. Journal of Economic Perspectives, Vol. 8. No. 1. 23-44. o. https://doi.org/10.1257/jep.8.1.23.

Grossman, G.-Helpman, E. [1994b]: Technology and Trade. NBER Working Papers, No. 4926. https://doi.org/10.3386/w4926.

Hall, P. A.-Soskice, D. [2001]: An Introduction to Varieties of Capitalism. Megjelent: Hall, P. A.-Soskice, D. (szerk.): Varieties of Capitalism. Oxford University Press, Oxford, 1-68. o. https://doi.org/10.1093/0199247757.003.0001. 
Halmai PÉTer [2014]: Krízis és növekedés az Európai Unióban. Európai modell, strukturális reformok. Akadémiai Kiadó, Budapest.

Halmai Péter-Vásáry Viktória [2012]: Convergence crisis: Economic crisis and convergence in the European Union. International Economics and Economic Policy, Vol. 9. No. 3-4. 297-322. o. https://doi.org/10.1007/s10368-012-0218-3.

Hansen, A. [1939]: Economic Progress and Declining Population Growth. The American Economic Review, Vol. 29. No. 1. 1-15. o. http://www.jstor.org/stable/1806983.

Hanushek, E. A.-Woessmann, L. [2012]: The Economic Benefit of Educational Reform in the European Union. CESifo Economic Studies, Vol. 58. No. 1. 73-109. o. https://doi. org/10.1093/cesifo/ifr032.

Havik, K.-McMorrow, K.-Röger, W.-Turrini, A. [2008]: The EU-US total factor productivity gap. An industry perspective. European Economy. Economic Papers, No. 39. https://doi.org/10.2765/95206.

Imbens, G.-Wooldridge, J. [2009]: Recent Developments in the Econometrics of Program Evaluation. Journal of Economic Literature, Vol. 47. No. 1. 5-86. o. https://doi.org/10.1257/ jel.47.1.5.

Jánossy Ferenc [1966]: A gazdasági fejlődés trendvonala és a helyreállítási periódusok. Közgazdasági és Jogi Könyvkiadó, Budapest.

JonEs, C. I. [2002]: Sources of US economic growth in a world of ideas. American Economic Review, Vol. 92. No. 1. 220-239. o. https://doi.org/10.1257/000282802760015685.

Kneller, R.-Bleaney, M.-Gemmell, N. [1999]: Fiscal Policy and Growth: Evidence from OECD Countries. Journal of Public Economics, Vol. 74. No. 2. 171-190. o. https://doi. org/10.1016/s0047-2727(99)00022-5.

Lucas, R. [1990]: Why Doesn't Capital Flow from Rich to Poor Countries? The American Economic Review, Vol. 80. No. 2. 92-96. o. http://www.jstor.org/stable/2006549.

Maddison, A. [1987]: Growth and Slowdown in Advanced Capitalist Economies: Techniques of Quantitative Assessment. Journal of Economic Literature, Vol. 25. No. 2. 649-98. o.

Maddison, A. [1996]: Macroeconomic Accounts for European Countries. Megjelent: Ark, B. van-Crafts, N. (szerk.): Quantitative Aspects of Post-war European Economic Growth. Cambridge University Press, Cambridge, 27-83. o. https://doi.org/10.1017/ cbo9780511599255.003.

Moкy , J. [2014]: Secular Stagnation? Not in Your Life. Megjelent: Teulings, C.-Baldwin, R. (szerk.): Secular Stagnation: Facts, Causes and Cures. CEPR Press, London, 83-89. o.

Nicoletti, G.-Scarpetta, S. [2005]: Regulation and Economic Performance: Product Market Reforms and Productivity in the OECD. OECD Economics Department, Working Papers, No. 460. OECD Publishing, https://doi.org/10.1787/463767160680.

North, D. C. [1990]: Institutions, Institutional Change and Economic Performance. Cambridge University Press, Cambridge, MA. https://doi.org/10.1017/cbo9780511808678.

OrLANDI, F. [2012]: Structural unemployment and its determinants in the EU countries. European Economy, Economic Papers, No. 455. European Commission DG ECFIN, Brüsszel.

Pichelmann, K. (szerk.) [2007]: The EU Economy: Review. Moving Europe's productivity frontier. European Economy, No. 8. European Commission DG ECFIN, Brüsszel.

Pichelmann, K. [2013]: Economic growth perspectives for Europe. Economic Brief. European Commission DG ECFIN, Brüsszel. 
Prasad, E.-Rajan, R.-Subramanian, A. [2007]: Foreign Capital and Economic Growth. Brookings Papers on Economic Activity, No. 1. 153-209. o. https://doi.org/10.1353/ eca.2007.0016.

Rivera-BAtiz, L. A.-Romer, P. [1991]: Economic Integration and Endogenous Growth. The Quarterly Journal of Economics, Vol. 106. No. 2.531-555. o. https://doi.org/10.2307/2937946. Snowdon, B.-VAne, H. R. [2006]: Modern Macsoeconomics. Edward Elgar, CheltenhamNorthampton, MA.

Summers, L. H. [2014]: U. S. Economic Prospects: Secular Stagnation, Hysteresis, and the Zero Lower Bound. Business Economics, Vol. 49. No. 2. 65-73. o. https://doi.org/10.1057/ be.2014.13.

Timmer, M. P.-InklaAR, R.-O’Mahony, M.-van Ark, B. [2010]: Economic Growth in Europe: A Comparative Industry Perspective. Cambridge University Press, Cambridge, MA. https://doi.org/10.1017/CBO9780511762703.

World BAnk [2009]: World Development Report Reshaping Economic Geography. The World Bank, Washington, D. C. https://doi.org/10.1596/978-0-8213-7607-2.

\section{Kedves Szerzőink!}

Az MTA Könyvtár és Információs Központtal együttműködve cikkeinket ellátjuk a CrossRef-nél regisztrált DOI-azonosítóval. Ezért kérjük, hogy a Hivatkozásokban tüntessék fel a művek DOl-azonosítóját (természetesen sokszor előfordul, hogy nincs ilyen). A DOI a következő linkre kattintva kereshető meg: http://search.crossref.org.

Például:

Boldrin, M.-Montes, A. [2005]: The intergenerational state: Education and pensions. Review of Economic Studies, Vol. 72. No. 3. 651-664. o.

A hivatkozott tételt bemásoljuk a keresőmezőbe, a találati listából pedig kiválasztjuk a megfelelő tételnél lévő hivatkozást, és beszúrjuk a hivatkozás végére: BoldRIN, M.-MontEs, A. [2005]: The intergenerational state. Education and pensions. Review of Economic Studies, Vol. 72. No. 3. 651-664. o. http://dx.doi.org/10. 1111/j.1467-937x.2005.00346.x.

Ne feledkezzenek meg a beszúrt hivatkozás hiperhivatkozásként való megjelöléséről a kéziratban!

A CrossRef-nél regisztrált DOI növeli a cikkek láthatóságát, könnyíti az adott, kapott hivatkozások összeszámlálását! 